\title{
Information Resources
}

Chapter 9 of

Section C, Techniques in Disease Surveillance and Investigation Book 15, Field Manual of Wildlife Diseases

Techniques and Methods 15-C9 



\section{Information Resources}

By Milton Friend

Chapter 9 of

Section C, Techniques in Disease Surveillance and Investigation

\section{Book 15, Field Manual of Wildlife Diseases}

Edited by J. Christian Franson, Milton Friend, Samantha E.J. Gibbs, and Margaret A. Wild

U.S. Geological Survey, U.S. Fish and Wildlife Service, and National Park Service

Techniques and Methods 15-C9 


\title{
U.S. Department of the Interior SALLY JEWELL, Secretary
}

\section{U.S. Geological Survey Suzette M. Kimball, Acting Director}

\author{
U.S. Geological Survey, Reston, Virginia: 2015
}

For more information on the USGS - the Federal source for science about the Earth, its natural and living resources, natural hazards, and the environment, visit http://www.usgs.gov or call 1-888-ASK-USGS.

For an overview of USGS information products, including maps, imagery, and publications, visit http://www.usgs.gov/pubprod.

To order this and other USGS information products, visit http://store.usgs.gov.

Any use of trade, firm, or product names is for descriptive purposes only and does not imply endorsement by the U.S. Government.

Although this information product, for the most part, is in the public domain, it also may contain copyrighted materials as noted in the text. Permission to reproduce copyrighted items must be secured from the copyright owner.

Suggested citation:

Friend, M., 2015, Information resources, in Franson, J.C., Friend, M., Gibbs, S.E.J., and Wild, M.A., eds. Field manual of wildlife diseases: U.S. Geological Survey Techniques and Methods, 15-C9, 23 p., http://dx.doi.org/10.3133/tm15c9.

ISSN 2328-7055 (online) 


\section{Contents}

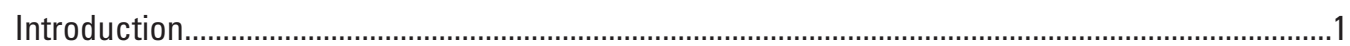

Federal Wildlife Disease Programs within the U.S. Department of the Interior ...............................3

National Wildlife Health Center......................................................................................................

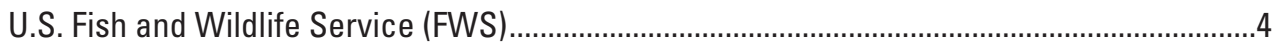

National Park Service (NPS) ............................................................................................ 4

Wildlife Disease Programs in Other Federal Departments..................................................................7

The National Oceanic and Atmospheric Administration (NOAA) ..............................................7

United States Department of Agriculture (USDA) ........................................................................

The Centers for Disease Control and Prevention (CDC) .........................................................

Regional Wildlife Disease Programs ..............................................................................................8

Southeastern Cooperative Wildlife Disease Study (SCWDS) ..................................................8

Northeast Wildlife Disease Cooperative (NWDC) ....................................................................

State Natural Resource Agency Wildlife Disease Programs...........................................................9

Alaska Department of Fish and Game (ADF\&G) ..................................................................

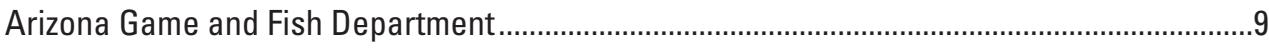

California Department of Fish and Wildlife (CDFW) ..............................................................

Colorado Parks and Wildlife ............................................................................................

Florida Fish and Wildlife Conservation Commission ..............................................................

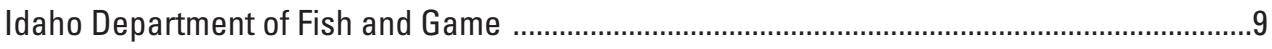

Kentucky Department of Fish and Wildlife Resources .............................................................10

Michigan Department of Natural Resources ................................................................................10

New York Department of Environmental Conservation ...............................................................10

Oregon Department of Fish and Wildlife .............................................................................10

Utah Division of Wildlife Resources ........................................................................................10

Wisconsin Department of Natural Resources (WDNR) ..........................................................10

Wyoming Game and Fish Department.....................................................................................10

University Based Wildlife Disease Programs .............................................................................11

Canadian Wildlife Health Cooperative ....................................................................................11

University of California-Davis-School of Veterinary Medicine ...............................................13

Colorado State University-College of Veterinary Medicine and Biological Sciences ...........13

Cornell University-College of Veterinary Medicine ...................................................................13

University of Florida-College of Veterinary Medicine ................................................................13

University of Georgia-College of Veterinary Medicine ...............................................................13

Michigan State University-College of Veterinary Medicine ........................................................13

Tufts University Cummings School of Veterinary Medicine ..........................................................13

University of Wisconsin-Madison-School of Veterinary Medicine ...........................................14

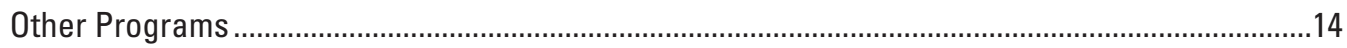

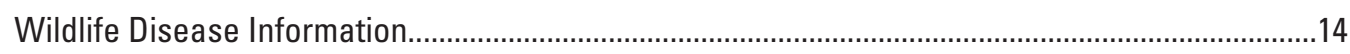

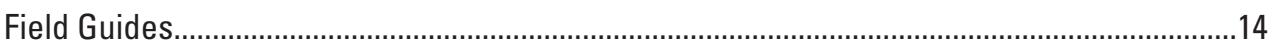

Other Selected Wildlife Disease References ...................................................................16

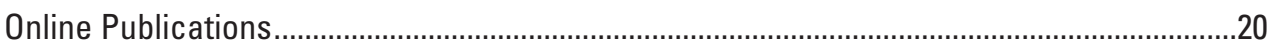

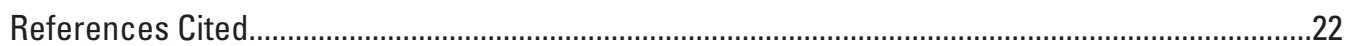




\section{Figures}

1. Photograph showing a Nebraska Game and Parks Commission employee collecting waterfowl carcasses during a spring epizootic of avian cholera.

2. Photographs showing three major North American multidimensional programs of relatively recent origin are devoted to addressing disease in free-ranging wildlife populations: the Southeastern Cooperative Wildlife Disease Study, the U.S. Geological Survey National Wildlife Health Center, and the Canadian Wildlife Health Cooperative

3. Schematic showing the movement of many infectious diseases between wildlife, domestic animals, and humans has resulted in increased multidisciplinary collaborative efforts to combat infectious disease emergence.

4. Photograph showing some of the estimated 40,000 waterfowl that died from duck plague, an exotic disease, at the Lake Andes National Wildlife Refuge in early 1973

5. Photograph showing wildlife conservation agency personnel learning field necropsy techniques, basic anatomy, and proper tissue collection techniques at a wildlife disease workshop..

6. Photograph showing veterinarians can provide specialized medical support when handling wildlife, particularly with endangered species such as this Florida panther in Big Cypress National Preserve

7A. Photograph showing National Park Service researchers collecting saliva sample from an immobilized elk in Rocky Mountain National Park to study chronic wasting disease......

7B. Photograph showing National Park Service researchers collecting blood from an immobilized elk in Rocky Mountain National Park to study chronic wasting disease

8. Photograph showing Canadian Wildlife Health Cooperative Western/Northern staff member checks a motion-triggered trail camera to collect information on how mule deer interact with the environment in southern Saskatchewan, Canada.

9. Photograph showing Canadian Wildlife Health Cooperative and Ontario Ministry of Natural Resources and Forestry research personnel prepare to collect a blood sample from an anesthetized adult male polar bear captured along the southern Hudson Bay coastline during the fall season

10. Photograph showing Canadian Wildlife Health Cooperative Western/Northern regional director tracks radio-collared mule deer for a chronic wasting disease research project in southern Saskatchewan, Canada

11. Schematic showing the period since the last half of the 20th century and continuing today has been marked by unprecedented global increases in infectious disease emergence and the resurgence of diseases once thought to have been adequately addressed 


\section{Tables}

1. Examples of illustrated field guides on wild life disease .............................................15

2. Examples of wildlife disease compendiums focused on specific geographic

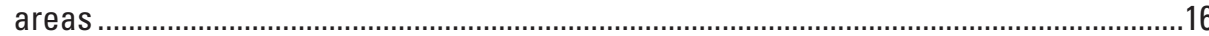

3. Examples of wildlife disease compendiums focused on specific wildlife species.........17

4. Examples of wildlife disease compendiums focused on specific types of

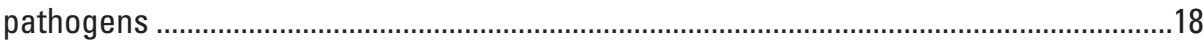

5. Examples of wildlife disease-oriented books focused on disease ecology and

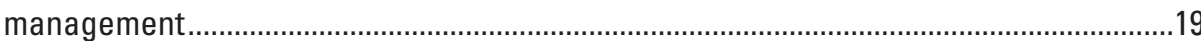

\section{Acknowledgments}

The author gratefully acknowledges the outstanding, responsive support and assistance provided by the National Wildlife Health Center (NWHC) librarian, Ms. Katherine Wesenberg, and her staff of student services contractors—specifically Mrs. Lindsay Barcus, Ms. Lindsay Farrell, Ms. Kelly Haberstroh, Ms. Hannah Lindquist, and Mr. Andrew King.

Their counsel, patience, and timeliness in responding to my many inquiries about electronic document systems and online publishing programs was invaluable, as was their timely acquisition of documents. Drs. John Fischer, Samantha Gibbs, Craig Stephen, and Margaret Wild provided the material on the Southeastern Cooperative Wildlife Disease Study, the Wildlife Health Office of the U.S. Fish and Wildlife Service National Wildlife Refuge System, the Canadian Wildlife Health Cooperative, and the National Park Service Wildlife Health Program, respectively. For context, my personal understanding of the electronic "new World order" for information capture and transfer prior to preparing this Chapter was akin to using engraved stone tablets for that purpose. I am also grateful for the administrative support provided by Ms. Jessica Kurtz, who typed the manuscript, maintained the associated electronic files, and attended to the numerous text and other adjustments needed between the initial draft and the final document 



\title{
Information Resources
}

\author{
By Milton Friend
}

\section{Introduction}

During recent decades, natural resources agency personnel and others involved with the management and stewardship of wildlife have experienced an increasing need to access information and obtain technical assistance for addressing a diverse array of wildlife disease issues (fig. 1). This Chapter provides a broad overview of selected sources for obtaining supplemental information and technical assistance for addressing wildlife disease issues in North America. Specifically, examples of existing major wildlife disease programs focusing on free-ranging wildlife populations are highlighted; training opportunities for enhancing within-agency wildlife disease response are identified; a selected reading list of wildlife disease references is provided; and selected Web sites providing timely information on wildlife disease are highlighted. No attempt is made to detail all the North American programs and capabilities that address disease in free-ranging wildlife populations. Instead, this Chapter is focused on enhancing awareness of the types of capabilities that exist as potential sources for assistance and collaboration between wildlife conservation agency personnel and others in addressing wildlife disease issues.

A wide variety of entities across North America are involved in wildlife disease investigations; however, the formal assembly of multidimensional programs that primarily address disease for the benefit of free-ranging wildlife is rather limited. The Southeastern Cooperative Wildlife Disease Study (SCWDS), the National Wildlife Health Center (NWHC), and the Canadian Wildlife Health Cooperative (CWHC) are selected examples (fig. 2). These programs are highlighted because of the scope of their capabilities and long-term involvement in assisting State and Federal natural resource agencies combat wildlife disease. A variety of other sources for possible assistance in addressing wildlife disease issues exists throughout North America and globally. It is prudent for wildlife conservation field biologists, managers, and administrators to be aware of such local resources. Ideally, awareness and knowledge of the types of assistance those programs can provide should be obtained prior to disease crisis events since appropriate, timely intervention often is required to minimize wildlife losses from disease and prevent the establishment of new infectious diseases within wildlife populations and geographic areas. Increasing recognition of the substantial number of infectious diseases being transferred between wildlife, domestic animals, and humans has led to increased collaborative investigations between wildlife, domestic, and human health programs (fig. 3). That collaboration has led to a heightened focus on wildlife disease within some public health

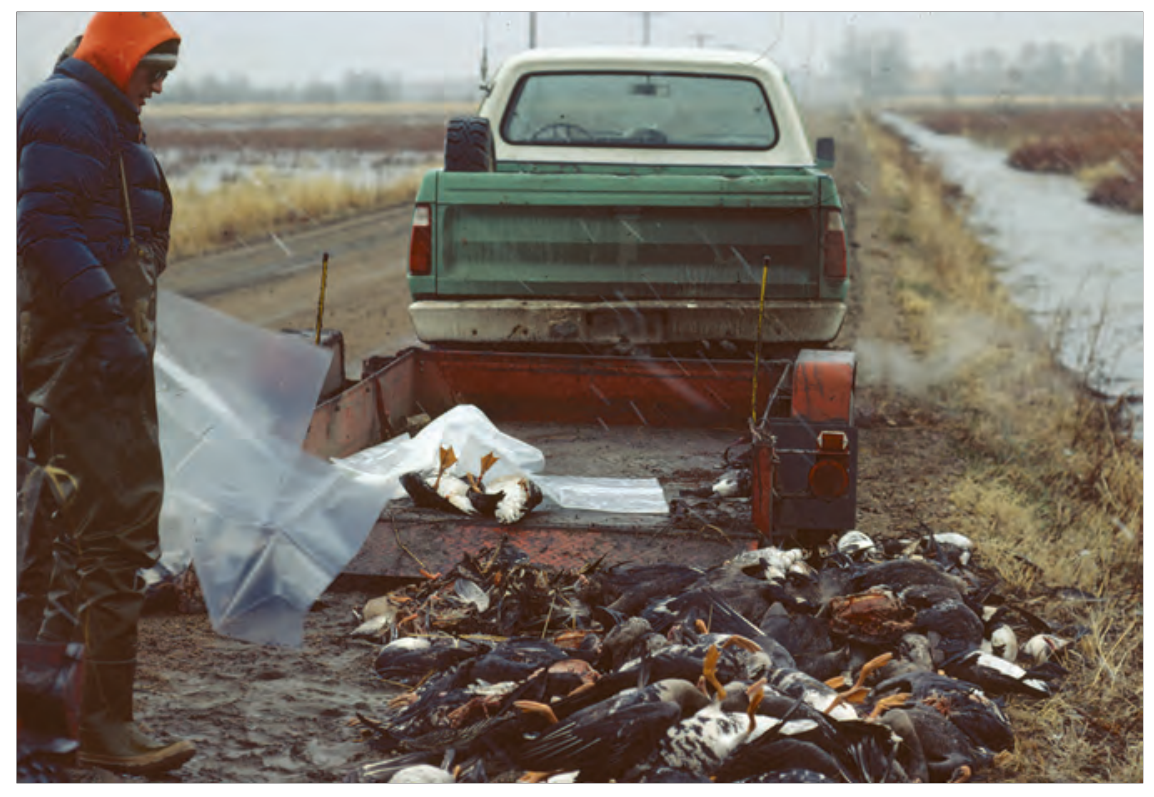

Figure 1. A Nebraska Game and Parks Commission employee collecting waterfowl carcasses during a spring epizootic of avian cholera. Since the end of the 1960s, North American wildlife conservation agency personnel have become increasingly challenged by disease emergence and resurgence in species under their stewardship. (Photo by Milton Friend) 
and agriculture agencies. For purposes of this Chapter, wildlife disease is narrowly defined as those diseases (infectious and noninfectious) causing morbidity and mortality in free-ranging wildlife populations. Therefore, there is no focus on the numerous fish disease or environmental contaminant programs that exist on behalf of North American fauna.

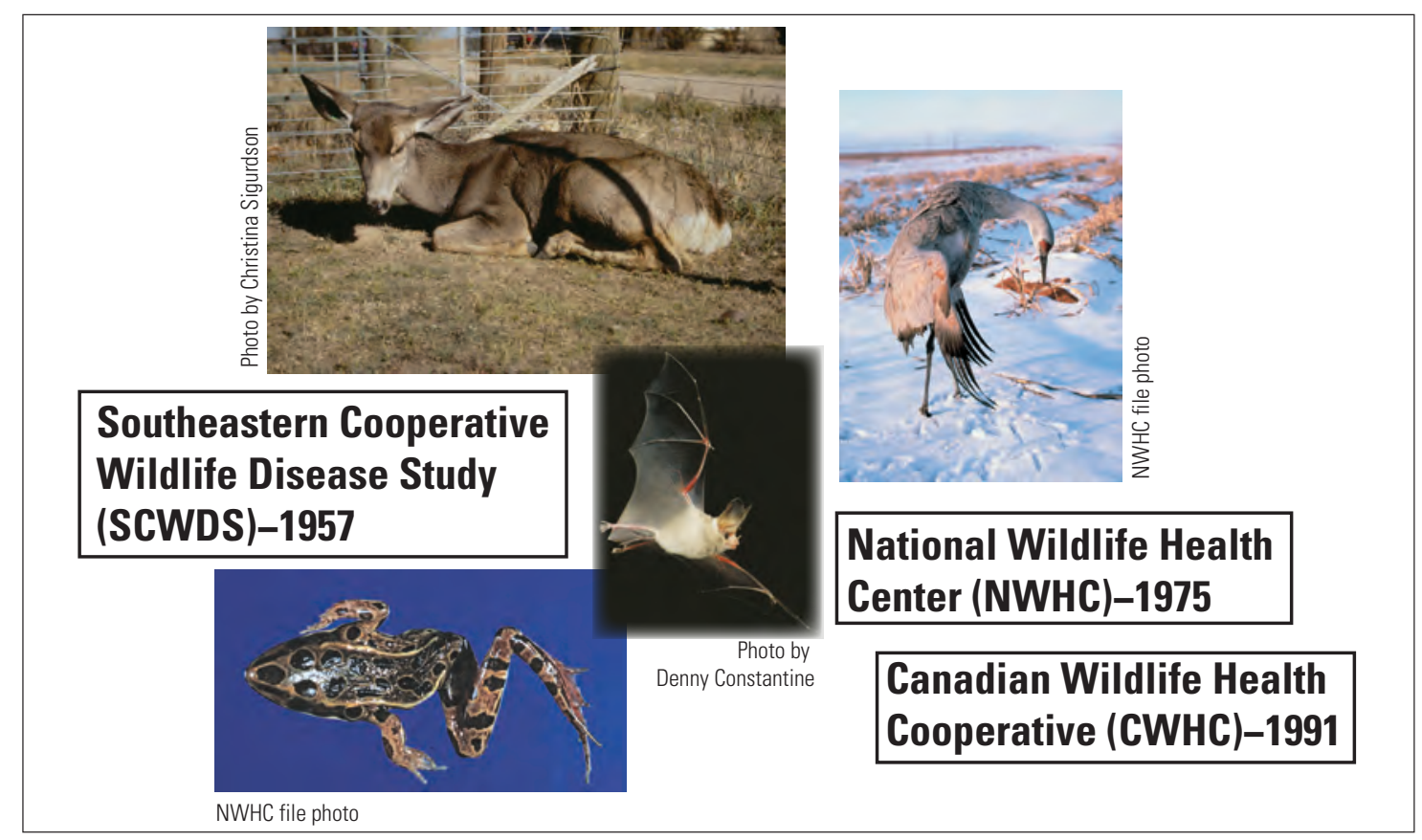

Figure 2. Three major North American multidimensional programs of relatively recent origin are devoted to addressing disease in free-ranging wildlife populations: the Southeastern Cooperative Wildlife Disease Study (SCWDS), the U.S. Geological Survey National Wildlife Health Center (NWHC), and the Canadian Wildlife Health Cooperative (CWHC). In 1957, SCWDS was the first program to be developed as a regional cooperative and championed by the Southeastern Association of Fish and Wildlife agencies. A Federal program - the NWHC — was initiated by the U.S. Fish and Wildlife Service in 1975 (18 years later), and became part of the U.S. Geological Survey in 1996. The university-based CWHC was established in 1991, known at that time as the Canadian Cooperative Wildlife Health Centre.

Figure 3. The movement of many infectious diseases between wildlife, domestic animals, and humans has resulted in increased multidisciplinary collaborative efforts to combat infectious disease emergence.

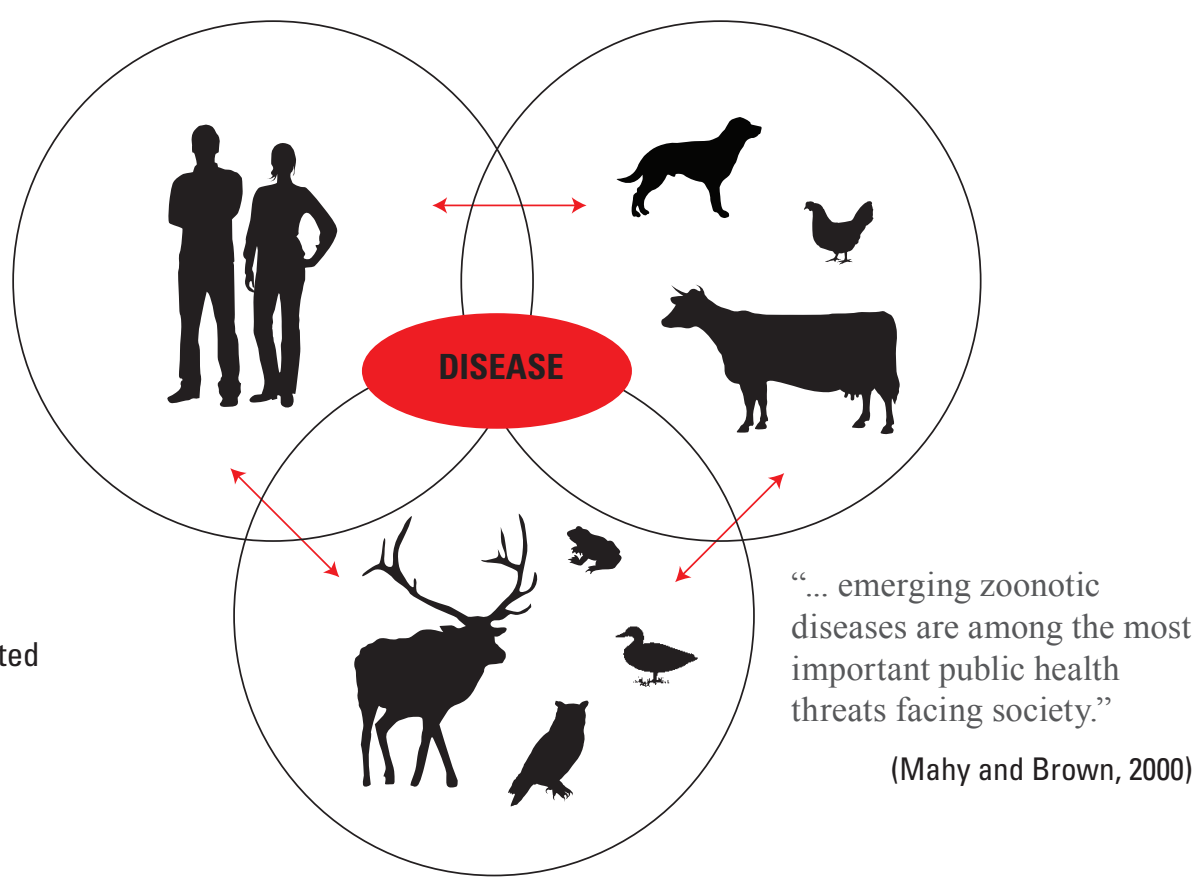




\section{Federal Wildlife Disease Programs within the U.S. Department of the Interior}

Three bureaus within the U.S. Department of the Interior (DOI) monitor, conduct research, or mitigate the effects of wildlife disease: the U.S. Geological Survey (USGS) National Wildlife Health Center (NWHC), the U.S. Fish and Wildlife Service (FWS) Wildlife Health Office, and the National Park Service (NPS) Wildlife Health Program. The contributions of each of the three DOI bureaus are described next.

\section{National Wildlife Health Center}

In January 1975, the FWS initiated what is now known as the NWHC as a new within-agency science program. That action was in response to the 1973 catastrophic duck plague (duck virus enteritis) epizootic at the Lake Andes National Wildlife Refuge in South Dakota (Friend and Pearson, 1973) (fig. 4). The occurrence of that exotic disease on a National Wildlife Refuge and the ensuing mass mortality of tens of thousands of waterfowl (despite a major FWS response involving the temporary assignment of dozens of employees to combat that crisis) highlighted the inadequacy of FWS capacity at that time to address disease in wildlife under agency stewardship. In response to that situation, the FWS invested in the development of the NWHC. This program has since been relocated to the USGS following successive reorganizations of biological science programs within the DOI.

In November 1993, the biological research components within the DOI, including those from the FWS, NPS, the Bureau of Land Management, the Bureau of Reclamation, and the Minerals Management Service were reorganized to form the National Biological Survey. That agency's name was changed to the National Biological Service (NBS) on January 5,1995 , to more accurately reflect the NBS mission (Friend, 1995). Three years later, the NBS was dissolved and its science programs were placed alongside the DOI long-standing physical science programs within the USGS. Throughout these transitions, the development of the NWHC "as a biomedical laboratory dedicated to assessing the impact of disease on wildlife and to identifying the role of various pathogens in contributing to wildlife loss" has remained the Center's focus.

The NWHC scientific activities are primarily focused on wildlife disease diagnostics, applied wildlife health research (for example, development of a vaccine to combat plague in the endangered black-footed ferret), and disease surveillance and outbreak investigations. The NWHC conducts enhanced epidemiological field investigations and disease ecology studies of emerging and recurring priority wildlife diseases; provides response and management consultation and training; and maintains, analyzes, and distributes comprehensive wildlife disease and mortality information in collaboration with a variety of governmental and nongovernmental partners.

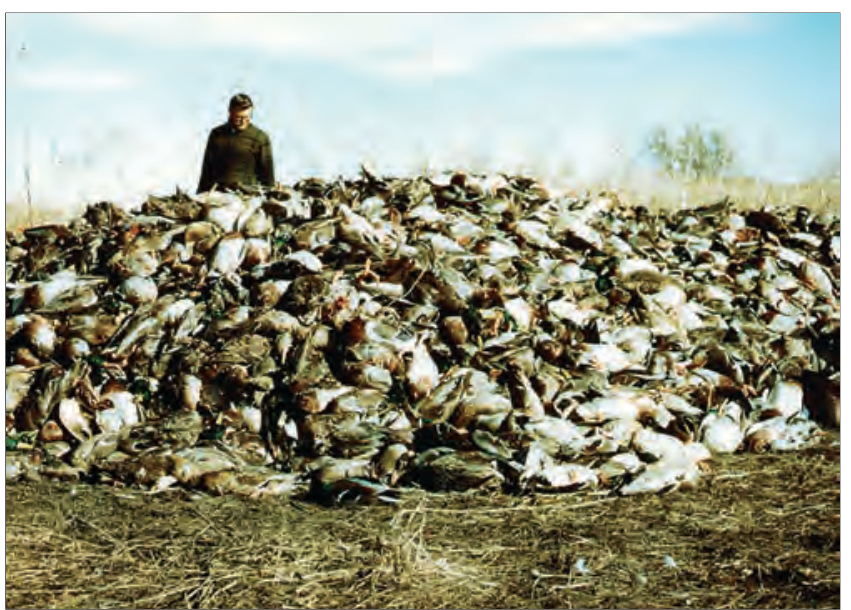

Figure 4. Some of the estimated 40,000 waterfowl that died from duck plague, an exotic disease, at the Lake Andes National Wildlife Refuge in early 1973. (Photo by Milton Friend)

The Wildlife Health Information Sharing Partnership event reporting system (WHISPers) (http://www.nwhc.usgs.gov/ whispers/) is a partner-driven repository for sharing basic information about historic and ongoing wildlife mortality and morbidity events. The primary goal of WHISPers is to provide natural resource management partners with timely, accurate information on where wildlife disease events are occurring or have occurred. The Center provides epidemiological and diagnostic services to Federal, State, and Tribal natural resources partners, largely free of charge to help investigate, understand, and manage unusual morbidity and mortality events as well as conducting surveillance for other diseases. Specimens also are accepted for surveillance of diseases of significance, such as suspected cases of duck plague, white-nose syndrome in bats, diseases of amphibians, and other diseases associated with epizootic mortality in wildlife. Diagnostic specimens must be submitted through, or in consultation with, an appropriate Federal, State, or Tribal agency and the NWHC point of contact. Submissions from the public and from rehabilitation facilities, universities, laboratories, and other entities generally are not accepted without prior consultation with the appropriate agency with species regulatory and management authority. See the NWHC Web site for a more detailed summary of these epidemiological and diagnostic services. Diagnostic case submission guidelines, request forms, and shipping instructions within that posting should be reviewed prior to contacting the NWHC. For consultation and requests for diagnostic services from the NWHC or to report wildlife mortality events in the lower 48 states, Alaska, or Puerto Rico, call (608-270-2480 or email nwhc-epi@usgs.gov). For Hawaii or the Pacific Island territories, contact the Center's Honolulu Field Station at 808792-9520 or email thierry.work@usgs.gov.

Center research partnerships and special projects are developed to foster comprehensive research products from the molecular to the landscape level. Such activities may require multidisciplinary NWHC teams and external partners, and 
may involve fiscal and (or) other support by the participating groups. Inquiries relative to the development of such partnerships and special projects should be directed to the Field Epidemiologist Team (nwhc-epi@usgs.gov). The NWHC also provides training programs for enhancing natural resource conservation and Tribal agency capacity to address wildlife disease issues. Most commonly, this involves classroom and hands-on workshops focused on wildlife health subject areas as requested by Federal, State, or Tribal agencies (fig. 5). Inquiries for such assistance should be directed as above (nwhc-epi@usgs.gov).

Center training activities also include hosting visiting scientists from other countries, mentoring university graduate and post-doctoral students and veterinary externs, and providing university classroom instruction and speakers for various venues to address specific wildlife disease issues. Inquiries relative to such activities should be directed to the Office of the NWHC Center Director by contacting Joanne Bosch via email jbosch@usgs.gov or via the U.S. Postal Service to USGS National Wildlife Health Center, 6006 Schroeder Road, Madison, WI 53711. Visit the NWHC Web site for additional information about Center activities and assistance provided.

The extent of disease issues is such that even within the DOI, internal needs of the FWS and NPS have resulted in disease specialists being incorporated within the programs of both agencies in addition to their being able to call upon the USGS NWHC on an "as needed" basis.

\section{U.S. Fish and Wildlife Service (FWS)}

The FWS National Wildlife Refuge System (NWRS) has a Wildlife Health office within the Natural Resource Program Center in Fort Collins, Colorado. The purpose of that office is to break the cycle of short-term reactionary approaches to one disease emergency at a time and move towards a preventionminded approach to wildlife health. Functional activities include wildlife health and disease surveillance as well as response to and management of disease events. This assistance is provided by a network of personnel across the country that supports the NWRS through technical advice about wildlife disease issues, guidance on adjusting management strategies to prevent wildlife diseases, identifying health surveillance needs, and conducting research projects to determine best practices in disease prevention.

The FWS also has a major role in the White Nose Syndrome Coordinated Response that includes development of the National Plan, funding continued surveillance and research efforts by partners, conducting surveillance in affected and unaffected areas, and determining the need for Federal protection of bat species impacted by this disease.

The FWS Forensics Laboratory is another within-agency program involved with wildlife mortality evaluations. It is the only laboratory in the world dedicated to investigating crimes against wildlife. The laboratory provides investigative support to all 50 State Fish and Game Commissions as well as to Federal agents (see also Chapters C6 and C7 of this Field Manual).

\section{National Park Service (NPS)}

The NPS established a Wildlife Health Program in 2000. Initial support for the program came from the NPS Natural Resource Challenge, a major effort to substantially improve how the NPS managed the natural resources under its care by understanding, measuring, and improving the health of park ecosystems. An NPS Wildlife Health Program was necessary to address wildlife health issues in the context of the unique mission and policies of the NPS (http://www.nature.nps.gov/ biology/wildlifehealth/index.cfm).

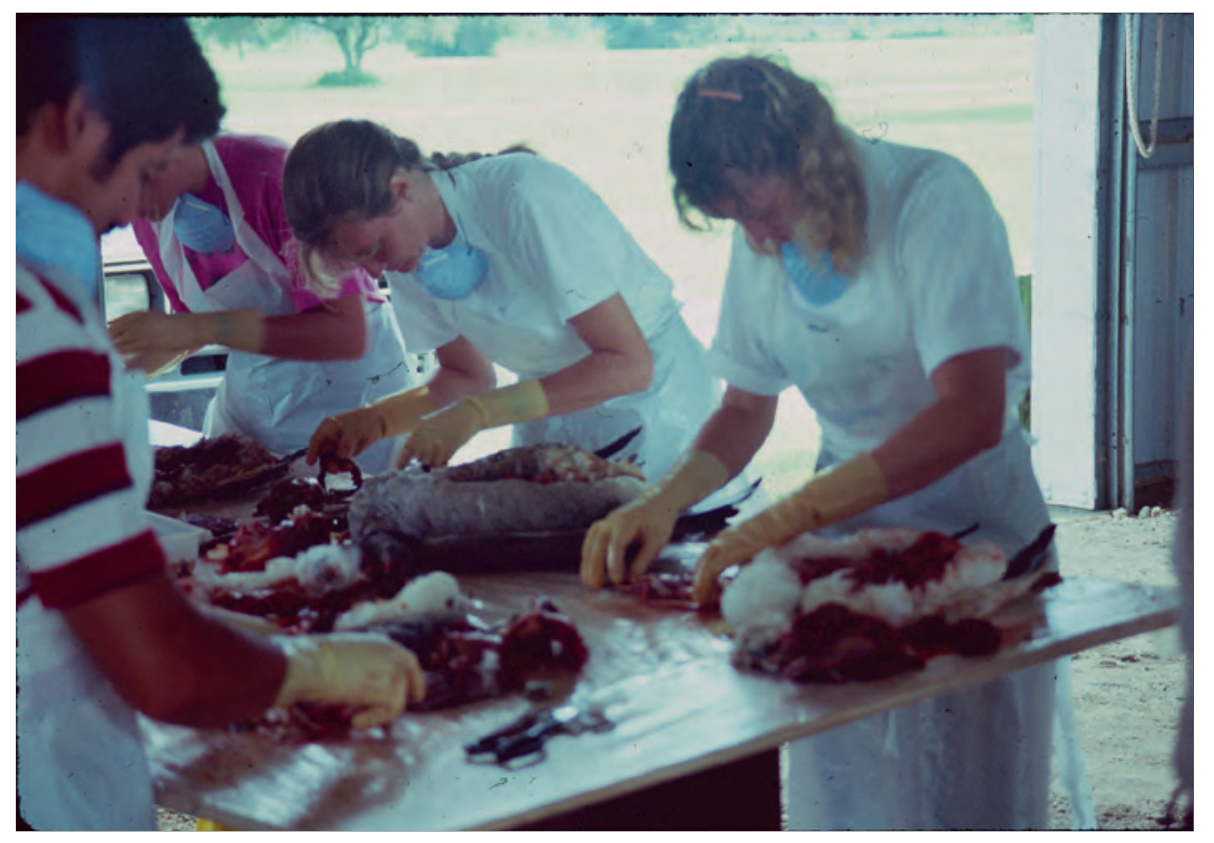

Figure 5, Wildlife conservation agency personnel learning field necropsy techniques, basic anatomy, and proper tissue collection techniques at a wildlife disease workshop. (Photo by Milton Friend) 
The NPS Wildlife Health Program provides professional veterinary consultation and technical assistance to aid parks in conserving wildlife by identifying and achieving wildlife health goals (fig. 6). The program is staffed with wildlife veterinarians, wildlife biologists, and wildlife and veterinary technicians. The team provides technical assistance to parks and policy recommendations to the NPS on a wide range of wildlife health issues including wildlife disease surveillance, monitoring, management, and research; disease outbreak investigations; disease ecology; field anesthesia; fertility control; and animal welfare, particularly through leadership and required veterinary oversight for the NPS Institutional Animal Care and Use Committee. The program works with parks to facilitate communication with States, other Federal agencies, and professional organizations on wildlife health issues. Through collaboration with partner agencies, a wildlife disease short course provides park staff with in-depth knowledge of wildlife diseases, sample collection and submission techniques, and safe work practices in the context of the NPS mission and policies. The program assists parks in putting what they learn in training into action by providing no-cost diagnostic services through partner university diagnostic laboratories and through collaboration with the NWHC.
The NPS Wildlife Health Program has developed preparedness and response plans for potentially catastrophic diseases such as foot-and-mouth disease and highly pathogenic avian influenza. Extensive guidance and reference material also has been prepared on issues such as chronic wasting disease, white-nose syndrome, sylvatic plague, and rabies to assist parks in preparation of management plans. Development of novel approaches to prevent and manage wildlife diseases without negatively impacting wildlife and associated resources or visitor experience is an ongoing program goal. Through management studies, program staff conduct cutting-edge research on live-animal tests for chronic wasting disease in deer and elk and the population impacts of the disease on elk (figs. $7 A$ and $7 B$ ) Computer modeling also is used to understand the effects of novel management approaches on disease.

The program works closely with the NPS Office of Public Health to promote the concept of One Health, which advocates cooperation between veterinary and human medicine and allied fields to improve the health of all species and the planet we share. The NPS is uniquely poised to implement and benefit from a One Health approach given the mission to conserve natural resources while welcoming nearly 3 million visitors annually. The NPS Office of Public Health is primarily

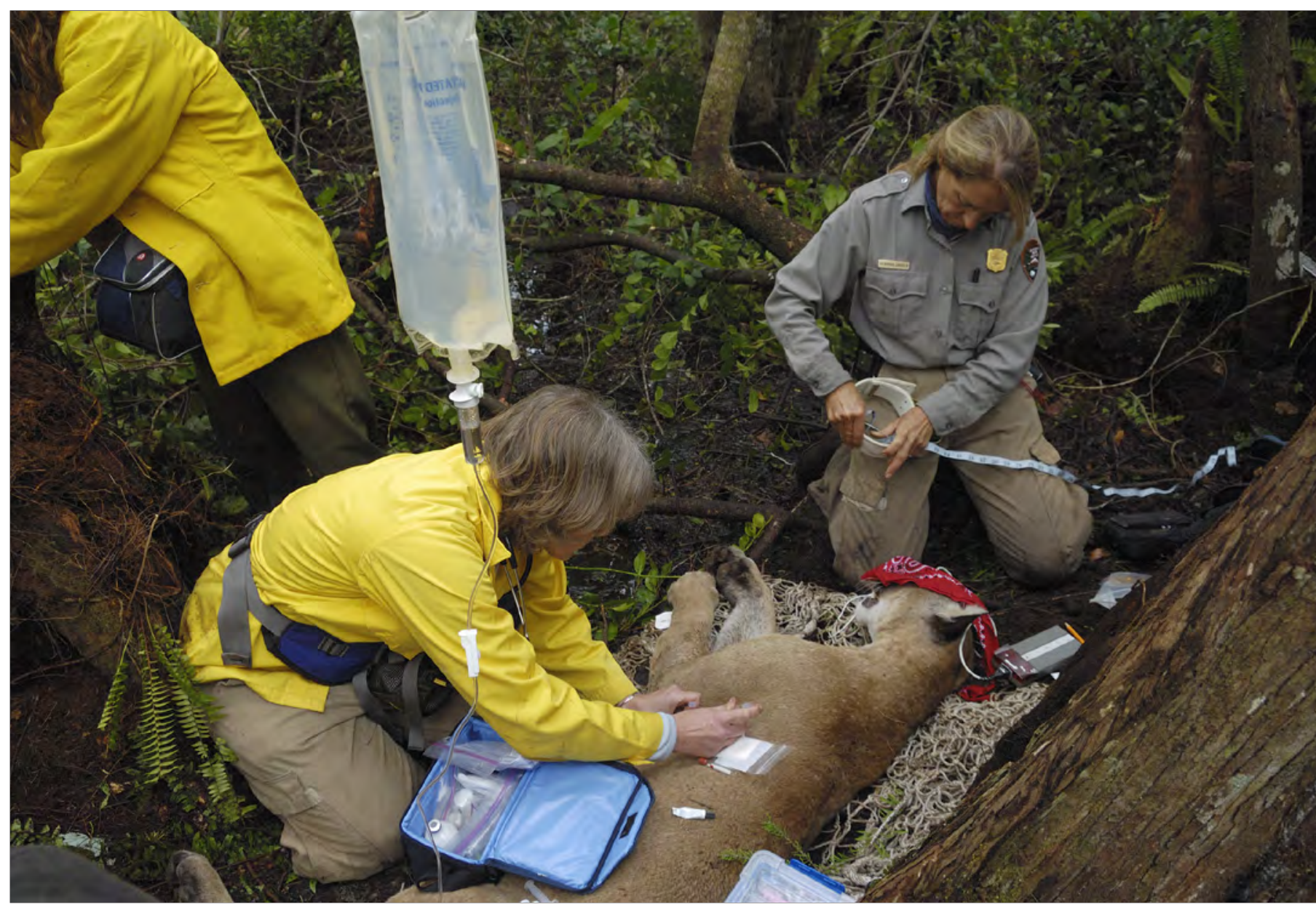

Figure 6. Veterinarians can provide specialized medical support when handling wildlife, particularly with endangered species such as this Florida panther in Big Cypress National Preserve. (Photo courtesy of Ralph Arwood) 


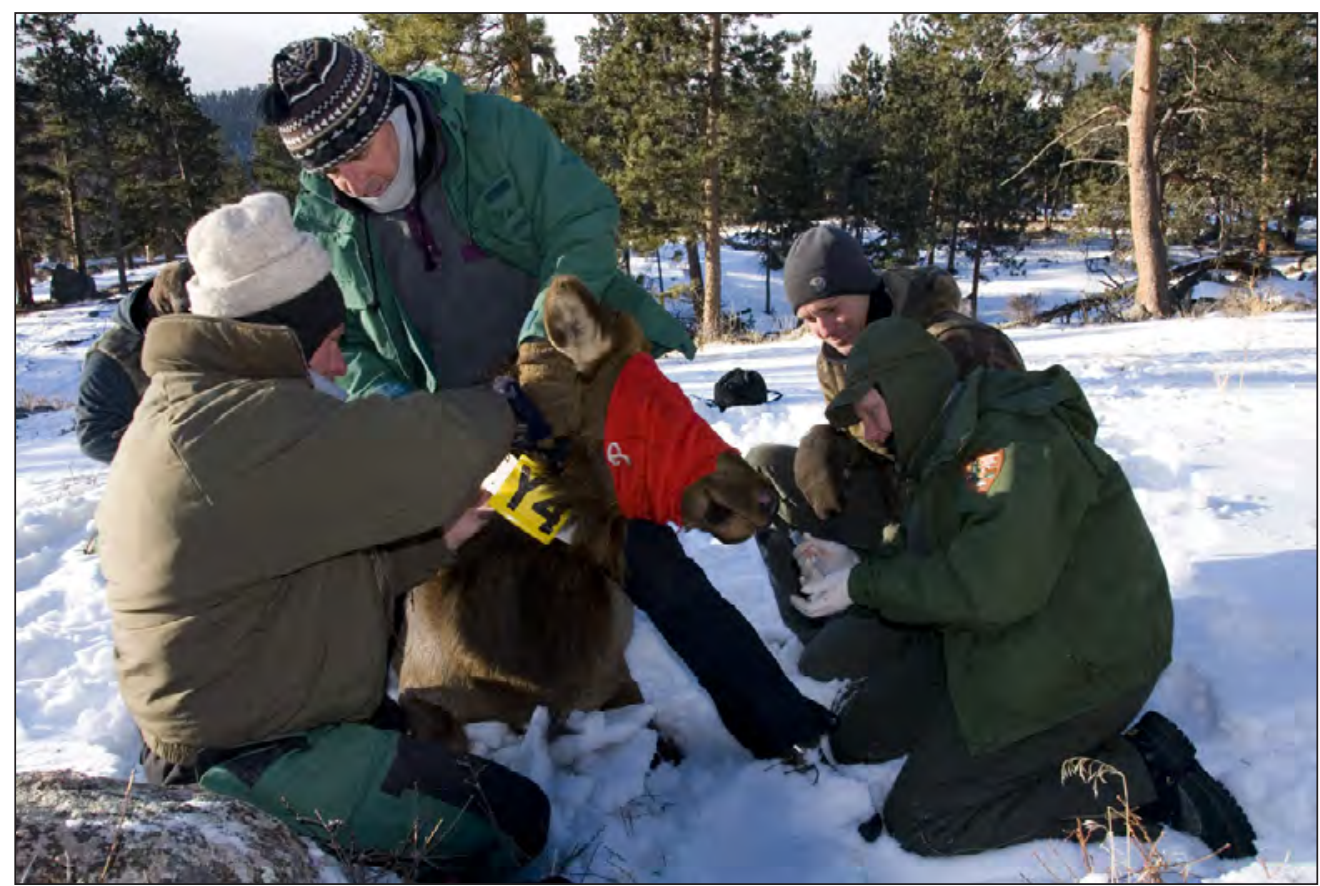

Figure 7A. National Park Service researchers collecting saliva sample from an immobilized elk in Rocky Mountain National Park to study chronic wasting disease. (Photo courtesy of James Frank)

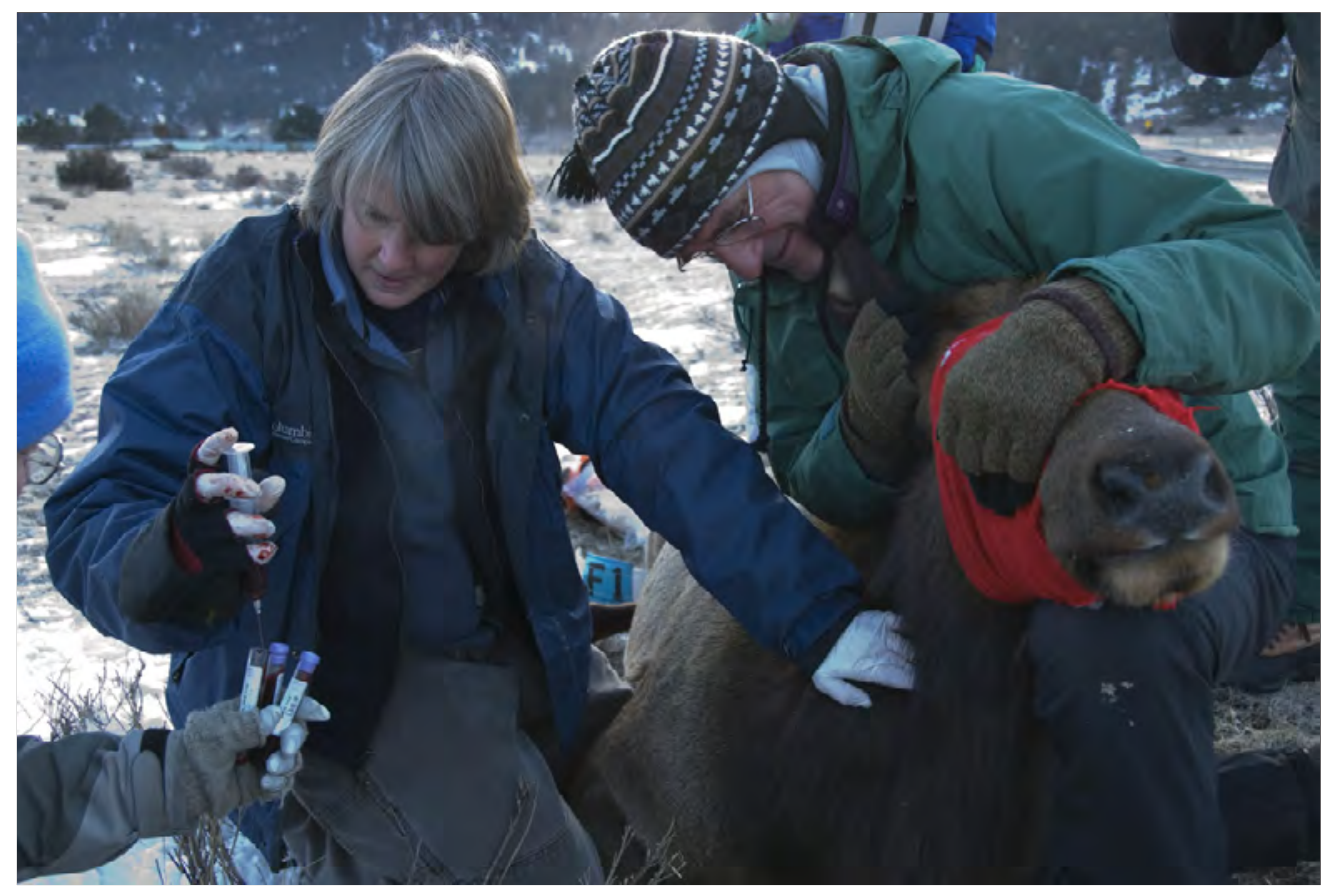

Figure 7B. National Park Service researchers collecting blood from an immobilized elk in Rocky Mountain National Park to study chronic wasting disease. (Photo courtesy of James Frank) 
staffed with commissioned officers of the U.S. Public Health Service that are on detail to the NPS. This includes one veterinary officer who serves as the One Health coordinator. Focal areas of collaboration include unified disease surveillance; integrated messaging on health topics that communicate the interconnectedness of the health of all species; collaborative research on biological and sociological aspects of diseases that are shared between humans and other animals; consensus recommendations on management tools that provide holistic, ecologically based science guidance; and interdisciplinary disease response. A hallmark of this collaboration is a disease outbreak investigation team consisting of a wildlife veterinarian, medical epidemiologist, and a public health consultant that is available to provide immediate technical expertise and assistance to parks on human and wildlife disease outbreaks.

Wildlife diseases and concerns about their impact on our national parks and risks to visitor health will likely continue to increase. The program and its collaboration with other wildlife and public health experts, land and wildlife management agencies, and researchers will play an important role in continuing to help parks protect wildlife health and welfare. For additional information on the NPS Wildlife Health Program, contact Dr. Margaret Wild, Chief Wildlife Veterinarian, National Park Service, Biological Resources Division, Wildlife Health Branch, 1201 Oak Ridge Dr., Suite 200, Fort Collins, CO 80525. Phone: (970) 225-3593, Cell: (970) 214-2886, email: margaret_wild@nps.gov.

In addition to DOI programs, other Federal agencies also are involved with wildlife disease investigations.

\section{Wildlife Disease Programs in Other Federal Departments}

\section{The National Oceanic and Atmospheric Administration (NOAA)}

The National Marine Fisheries Service Marine Mammal Health and Stranding Response Program resulted from the 1992 Amendments to the Marine Mammal Protection Act. Program components are (1) the development of marine mammal stranding networks, (2) implementation of responses/ investigations of mortality events, (3) bio-monitoring, (4) tissue/serum banking, and (5) analytical quality assurance. This program assesses the health and contaminant loads of marine mammals to monitor trends and investigate the impacts of disease, natural toxins, and pollution on marine animal populations. The NOAA Fisheries Web site (http://www.nmfs.noaa. gov/pr/health/report.htm) provides a listing of participating universities, aquariums, wildlife agencies, and other collaborators for reporting stranded/beached marine animals. Telephone numbers are provided for specific programs by geographic region and State.
The National Marine Mammal Tissue Bank component of the above program is maintained by the National Institute of Standards and Technology and is an important component of global biomonitoring efforts to help assess the health and contaminant loads of marine mammals, marine food chains, and marine ecosystems. This program provides long-term archiving of samples to facilitate trend and retrospective analyses. Response to marine mammal disease issues in the U.S. is complicated by the fact that some species fall under the authority of NOAA and others under the FWS. The FWS has responsibility for polar bear, walrus, sea otter, manatee, and species classified as threatened or endangered under the Federal Endangered Species Act.

\section{United States Department of Agriculture (USDA)}

The National Animal Disease Center (NADC) in Ames, Iowa, is the largest Federal animal disease center in the United States. Organizationally, the NADC is part of the USDA Agricultural Research Service. Its mission is to prevent disease transmission among livestock and poultry to reduce the economic losses from infectious, genetic, and metabolic diseases, including diseases shared with wildlife. Bovine tuberculosis in white-tailed deer has been one of the topics related to wildlife investigations. The NADC activities also extend to food safety by reducing or eliminating pre-harvest contamination of infection of livestock and poultry with food-borne human pathogens. Also in Ames is the Animal and Plant Health Inspection Service-Veterinary Services National Veterinary Services Laboratories, which provides diagnostic support and confirmation of many diseases of concern, such as avian influenza and chronic wasting disease (CWD).

The USDA also has a National Wildlife Disease Program (NWDP) as a component of the agency's Animal and Plant Health Inspection Service (APHIS) Wildlife Services Program. The NWDP is headquartered at the National Wildlife Research Center in Fort Collins, Colorado, and participates in wildlife disease monitoring and surveillance in all regions of the United States. Wildlife disease biologists serve as first responders for the program's Surveillance and Emergency Response System and also assist many State, Federal, Tribal, and international agencies as well as private cooperatives with education and outreach to develop wildlife disease monitoring programs. That program has been heavily involved in working with State wildlife agencies on CWD management. 


\section{The Centers for Disease Control and Prevention (CDC)}

The CDC has developed a wildlife initiative for providing information for health professionals and the general public on specific zoonotic diseases transmitted by wildlife. The CDC has a long history of collaborative investigations with wildlife conservation agencies in addressing zoonotic diseases, such as rabies, tularemia, and sylvatic plague. This role has expanded greatly since the early 1980s due to the global increase in infectious disease emergence and is in part reflected in that agency's publication of Emerging Infectious Diseases (www. cdc.gov/eid), a peer-reviewed journal tracking and analyzing disease trends. West Nile virus and avian influenza are examples of current diseases under collaborative investigation by the CDC and wildlife agencies.

\section{Regional Wildlife Disease Programs}

Government wildlife conservation agencies have a long history of developing partnerships with other agencies and programs to obtain specialized assistance needed to address scientific and other issues challenging the conservation of freeranging wildlife under agency stewardship. Given the costs associated with the specialized needs associated with facilities, equipment, and specialists required to address the major challenges from wildlife disease, it is logical that cooperative programs be considered that fund a single source to serve a broad spectrum of user groups. Numerous attempts have been and continue to be made to achieve that purpose. The following examples highlight different types of wildlife disease programs that have been successful in advancing the capacity of wildlife conservation agencies to address their internal needs for controlling disease in free-ranging wildlife populations.

\section{Southeastern Cooperative Wildlife Disease Study (SCWDS)}

This program was formed by 11 States within the Southeastern Association of Fish and Wildlife Agencies on July 1, 1957. The catalyst for this action was a series of hemorrhagic disease epizootics taking a large toll of whitetailed deer across a wide geographic area. Since its inception, SCWDS, located at the University of Georgia's College of Veterinary Medicine in Athens, Georgia, has been a major program combatting wildlife disease. The SCWDS program does not duplicate the efforts of any existing State or Federal laboratory or agency but, instead, provides research, diagnostics, and services of scope and quality that otherwise would not be available. Currently (2015), the wildlife agencies of 18 States and the DOI, through the USGS and the FWS fund regional wildlife research and service projects. SCWDS also is supported by Veterinary Services and Wildlife Services of the USDA APHIS, for consultation and surveillance on a national and international basis where diseases may interact among wildlife, domestic livestock, poultry, and humans.

The collective activities of SCWDS have resulted in the publication of many articles in scientific journals and symposia, and many books. "Diseases and Parasites of White-Tailed Deer," a book edited by SCWDS personnel, further establishes SCWDS as a reference center for information on diseases and parasites of this Nation's number one big game animal. The "Field Manual of Wildlife Diseases in the Southeastern United States," now in its third edition, was first published in 1988 and is used by biologists, veterinarians, and others throughout the region and elsewhere. SCWDS produces other informational materials that are useful for training and public education, such as the quarterly newsletter "SCWDS Briefs" and brochures on important wildlife disease topics. Training for wildlife biologists and veterinary medical officers has become an important mission for SCWDS in recent years. Wildlife disease workshops or special programs designed to acquaint field personnel and administrators with major wildlife disease topics have been conducted in 19 States.

As an academic institution, SCWDS participates in educational activities of undergraduate, graduate, and veterinary students at the University of Georgia, as well as externs from other colleges of veterinary medicine. SCWDS faculty members acquire grants and cooperative agreements to conduct work that is of benefit to its supporters. In addition, grants sometimes support SCWDS graduate students. Students who obtained graduate degrees at SCWDS have gone on to work across the country for State and Federal wildlife management, animal agriculture, and public health agencies.

\section{Northeast Wildlife Disease Cooperative (NWDC)}

During recent years, several other State wildlife conservation agencies also have been pursuing the further development of regional wildlife disease cooperatives to meet their needs. The Northeast Wildlife Disease Cooperative is currently receiving the greatest attention for advancement as a fully integrated regional program. That Cooperative utilizes formal collaborative associations between State wildlife conservation agencies, the university community, and others. Its primary focus is on providing cost-effective and efficient wildlife disease diagnostic services for member agencies as well as advising agencies in the management of disease events. Collaborating States pay a nominal fee to join the Cooperative and receive services on a pay-as-you-go basis. 


\section{State Natural Resource Agency Wildlife Disease Programs}

In addition to the previously mentioned programs, numerous State wildlife conservation agencies have invested in internal wildlife disease capabilities. The examples that follow illustrate the wide diversity of approaches taken.

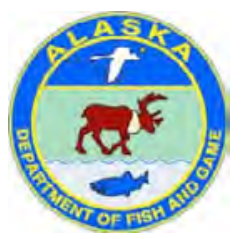

\section{Alaska Department of Fish and Game (ADF\&G)}

The ADF\&G's home page has a Parasites and Diseases Overview that directs readers to the ADF\&G's wildlife disease focus areas. The first is a downloadable Adobe Acrobat portable document format (PDF) file, "Descriptions and risks of some common wildlife diseases and parasites potentially infecting game meat." This is an important document given the high subsistence use of fish and game by many Alaskans. The second is another PDF that provides instructions and a form for "Submitting Samples for Disease/Parasite Investigations" to the ADF\&G Wildlife Veterinary Science facility in Fairbanks. Also included is information (with associated PDFs) on Alaskan "Wildlife Disease and Parasites in the News" and a listing of "Diseases of Concern".

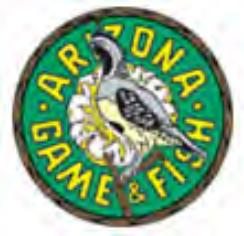

\section{Arizona Game and Fish Department}

Although CWD has not been detected in Arizona (as of January 2015), the Arizona Game and Fish Department monitors its deer and elk populations to reduce the likelihood for this disease becoming established in Arizona from neighboring States where it is present. In addition, the Arizona Game and Fish Department responds to other diseases of concern such as sylvatic plague, rabies, tularemia, hantavirus, and West Nile fever - all of which are zoonoses (https://azgfdportal.az.gov/Wildlife/Diseases).

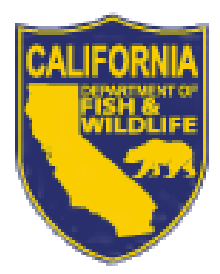

\section{California Department of Fish and Wildlife (CDFW)}

The CDFW's Wildlife Investigations Laboratory was established in 1941 and is mandated by Fish and Wildlife Code to conduct wildlife disease investigations. Current responsibilities of the laboratory include wildlife disease surveillance and investigations, biological sampling, and providing training courses related to wildlife handling, restraint, and necropsy. Additional activities include disease surveillance and health monitoring to determine population trends, health status, demographics, and habitat use information.

The CDFW's Marine Wildlife Veterinary Care and Research Center was constructed in 1997 as the primary core facility for sea otters affected by oil spills or other marine pollution events (https://www.wildlife.ca.gov/OSPR/Science/ MWVCRC). The CDFW staff also conduct research pertaining to southern sea otter pathology and biology. Other activities include research on pinniped health, seabird health, and terrestrial animal disease vectors.

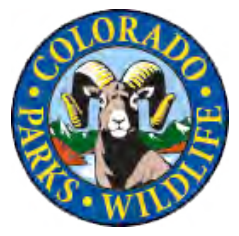

\section{Colorado Parks and Wildlife}

The Colorado Parks and WildlifeWildlife Health Section diagnoses, monitors, and conducts disease-related research and diagnostic services on the States free-ranging wildlife. The Section's focus for research is on diseases that affect the long-term survival of wildlife populations or prevent the growth of those populations.

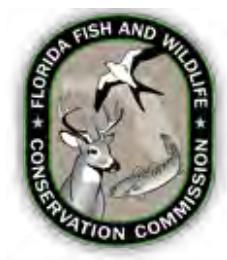

\section{Florida Fish and Wildlife Conservation Commission}

The Wildlife Health team stationed at the Wildlife Research Laboratory in Gainesville consists of wildlife veterinarians, wildlife biologists, support staff, and volunteers. This team is responsible for monitoring terrestrial wildlife disease throughout Florida, in addition to conducting research in the field of wildlife health. The research laboratory is home to a necropsy laboratory where the Wildlife Health team can examine and study various wildlife species.

The Florida Fish and Wildlife Conservation CommissionFish and Wildlife Research Institute monitors the State's marine and estuarine systems for signs of disease and environmental stressors including die-offs, fish kills, red tides, poor water quality, and biological toxins in order to develop aquatic disease and disease management guidelines throughout the State.

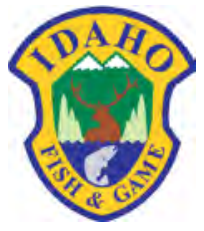

\section{Idaho Department of Fish and Game}

The Idaho Department of Fish and Game-Wildlife Health Laboratory within the Wildlife Bureau is the primary group that deals with wildlife in the State. Addressing disease in free-ranging wildlife is one of the Department's high priorities. Collaboration with the Idaho Department of Agriculture-Animal Health Laboratory facilitates research and diagnostic pursuits involving diseases of mutual interest. 


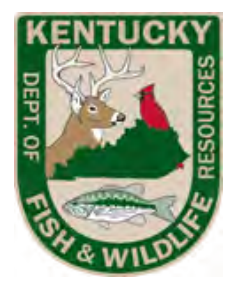

\section{Kentucky Department of Fish and Wildlife Resources}

The Kentucky Department of Fish and Wildlife Resources-Wildlife Health Program is a new branch of the Department and includes the State wildlife

veterinarian and support staff in a new Wildlife Health Annex with a laboratory and diagnostic center for diseases and other health issues that affect Kentucky's fish and wildlife. This new program also supports other Department programs and collaborates with other State agencies such as the Departments of Agriculture and Public Health.

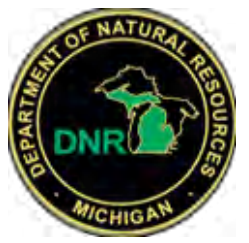

\section{Michigan Department of Natural Resources}

The Michigan Department of Fish and Wildlife Resources-Wildlife Disease Laboratory is responsible for monitoring the health and well-being of Michigan's wildlife. It is one of the earliest programs of its type developed within a State wildlife conservation agency in the United States, dating back to 1934. Since August 2004, the laboratory has been housed at the Diagnostic Center for Population and Animal Health on the Michigan State University Campus. That Center is a state-of-the-art animal health diagnostic and service facility that affords the Department outstanding support capabilities for disease diagnosis.

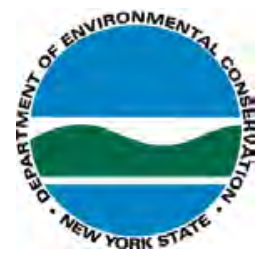

\section{New York Department of Environmental Conservation}

The New York Department of Environmental Conservation-Wildlife Health Program was one of the earliest among State natural resource agencies and continues to evolve with changing times and needs. The current program is a partnership with the Cornell University College of Veterinary Medicine-Animal Health Diagnostic Center. The stated goal "is to identify and monitor both infectious and noninfectious diseases in wildlife populations; to put that information to use in making sound management decisions; and to intervene when necessary to ensure that New York has sustainable, robust, and diverse wildlife populations for the future." The Department maintains a Wildlife Health Unit at its Wildlife Resources Center near Albany. Necropsies and other diagnostic procedures for wildlife submissions are conducted at that location by Health Unit Staff. That staff also provide forensic pathology in support of wildlife law enforcement activities; conduct field investigations relative to the impacts of environment contamination on wildlife; and carry out original research in the fields of wildlife pathology, physiology, and toxicology.

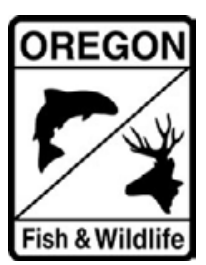

\section{Oregon Department of Fish and Wildlife}

The Oregon Department of Fish and Wildlife has an internal Fish and Wildlife Health and Population Laboratory whose staff collaborates with the Oregon State UniversityVeterinary Diagnostic Laboratory during wildlife disease diagnostic investigations. Collaborative research projects also occur between these entities. Health and Population Laboratory staff also conduct statewide wildlife disease investigations and surveillance as well as providing support for the Department's Fish Pathology Laboratory and hatcheries, marine fisheries responsibilities, and its marine mammal programs.

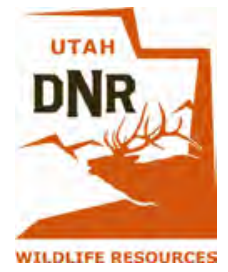

\section{Utah Division of Wildlife Resources}

The Utah Division of Wildlife Resources-Wildlife Disease Program is focused on monitoring and controlling diseases of concern, investigating sick or dead wildlife reported by wildlife authorities and the public, assessing the effects of disease in Utah's wildlife populations, and reducing or eliminating diseases that threaten the health and vitality of Utah's wildlife, or that pose a human health risk.

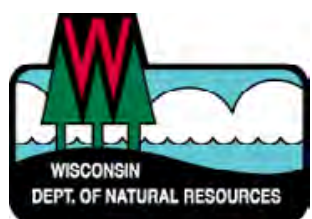

\section{Wisconsin Department of Natural Resources (WDNR)}

The WDNR-Wildlife Health Program employs specialists to address wildlife toxicology, infectious, and other forms of disease threatening wildlife under WDNR stewardship. Wildlife rehabilitation also is part of the wildlife health program because licensed rehabilitators are involved in monitoring wildlife health, and often are at the forefront of disease detection. Much of the Department's focus during recent years has been on combatting CWD; however, a broad spectrum of diseases is addressed. Since 2008, the WDNR also has had major involvement in the surveillance and research efforts to combat avian botulism, type E within the Great Lakes ecosystem. Disease diagnostic and response capabilities are enhanced by collaborative relations the WDNR enjoys with the Wisconsin Veterinary Diagnostic Laboratory and the NWHC.

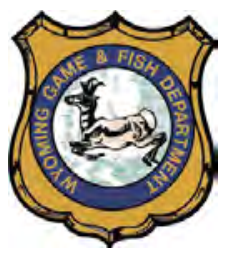

\section{Wyoming Game and Fish Department}

The Wyoming Game and Fish Department has two major facilities involved in the investigation of wildlife mortality. The Tom Thorne and Beth Williams Wildlife Research Center at Sybille is devoted to research on important diseases of Wyoming 
wildlife such as brucellosis, CWD, and pasteurellosis, in addition to focusing on endangered species capture techniques, wildlife propagation, wildlife nutrition, physiology, and genetics. The Department's Wildlife Disease Laboratory is responsible for monitoring wildlife disease throughout the State. The Laboratory focuses on diseases of large mammals, but strives to provide diagnostics for all species.

\section{University-based Wildlife Disease Programs}

The university community has been an important ally in combatting wildlife disease since the start of modern wildlife conservation in North America. The increasing focus during recent years on wildlife disease has resulted in expanded general interest in combatting such diseases because of "One Health" interests (The World Bank, 2010; Kayunze and others, 2014) as well as secular concerns within the wildlife, domestic animal, and public health arenas. Several schools of veterinary medicine and other academic institutions have developed and (or) expanded their internal programs to include population level disease investigations focused on free-ranging wildlife populations. Some of those programs also are providing advanced support capacity for combatting wildlife disease epizootics. The Canadian Wildlife Health Cooperative (CWHC) is a major example.

\section{Canadian Wildlife Health Cooperative}

The CWHC is dedicated to promoting and protecting the health of wildlife and Canadians through leadership, partnership, investigation, and action to ensure a world that is safe and sustainable for wildlife and for humans. It is Canada's only national wildlife health program. Through its programs of surveillance, assessment, investigation, and response, the CWHC links conservation, public health, and economic activities to provide assurances that the relationships between people, wildlife, and their shared environment remain healthy and safe (fig.8). The CWHC provides a nationally credible and respected voice that can facilitate strategies, decisions, and actions to protect wildlife and the services they provide to Canadians. The CWHC combines a national perspective on Canada's wildlife health situation, coordinates national programs, and responds to local needs to document and understand the status of wildlife health.

The CWHC is a pan-Canadian network of wildlife health practitioners and investigators grounded in each of Canada's five veterinary colleges but with partnerships with federal, provincial, and territorial partners concerned with human health, agriculture, conservation, and natural resource management. Links to the nonprofit sector, corporate Canada, and citizen scientists are being built into the CWHC network. The trusted, reliable, and sustained connection between knowledge

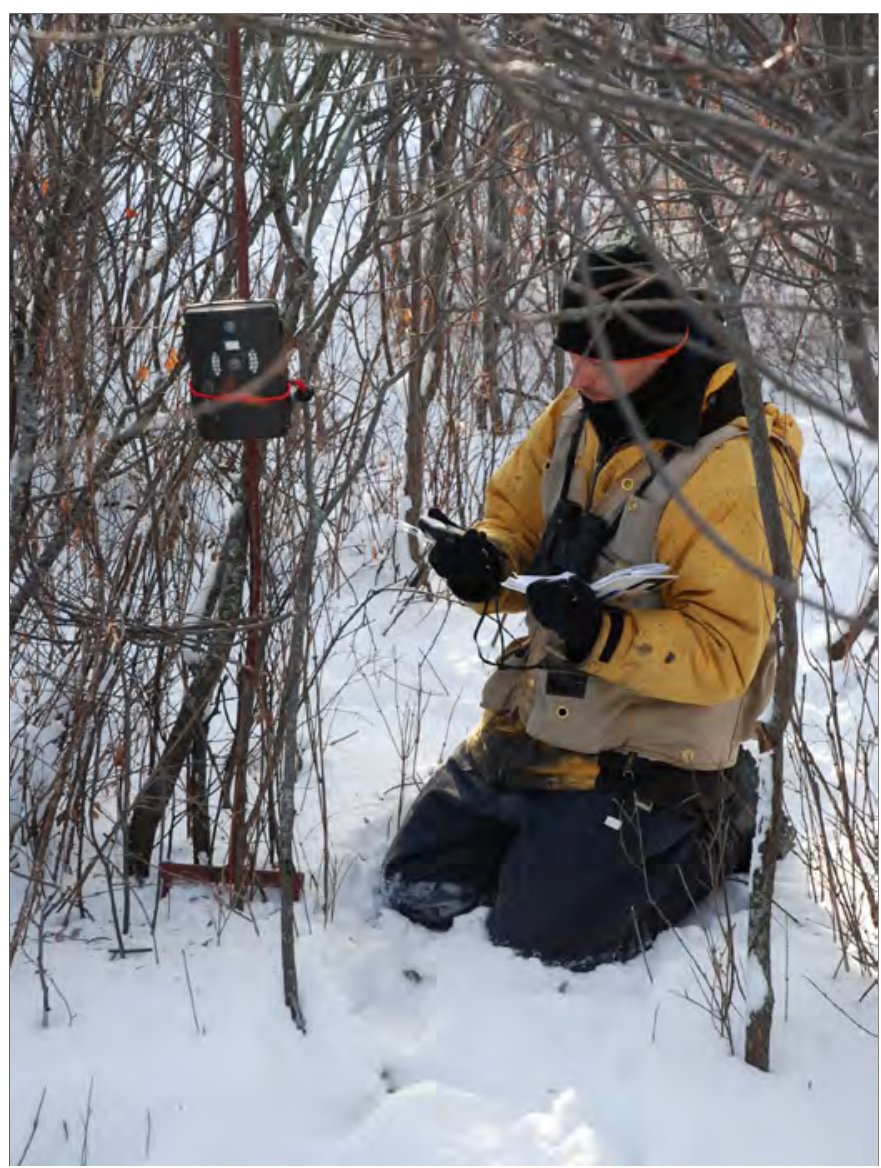

Figure 8. Canadian Wildlife Health Cooperative Western/ Northern staff member checks a motion-triggered trail camera to collect information on how mule deer interact with the environment in southern Saskatchewan, Canada. (Photo courtesy of Canadian Wildlife Health Cooperative)

producers and knowledge users shortens the time between threat detection, threat assessment, information dissemination, and response. As a neutral knowledge broker, the CWHC facilitates and enables teams to turn knowledge into management action.

The CWHC is Canada's wildlife health focal point to coordinate and link federal, provincial, and territorial programs, priorities and information. Its network of diagnostic services attracts a sufficient number of geographic representative samples that are ongoing and sustainable, and are analysed and reported using methods that meet international standards. This national sentinel program helps to identify and triage environmental threats manifested in wildlife to identify response priorities or provide assurances of the absence of specific threats (fig.9). The scanning surveillance is supplemented with active surveys or targeted surveillance for specific hazards (fig.10). By linking animal health outcomes to the situations and circumstances where those animals were found, the CWHC documents biological effects of environmental changes linked to development, changes in land use, 


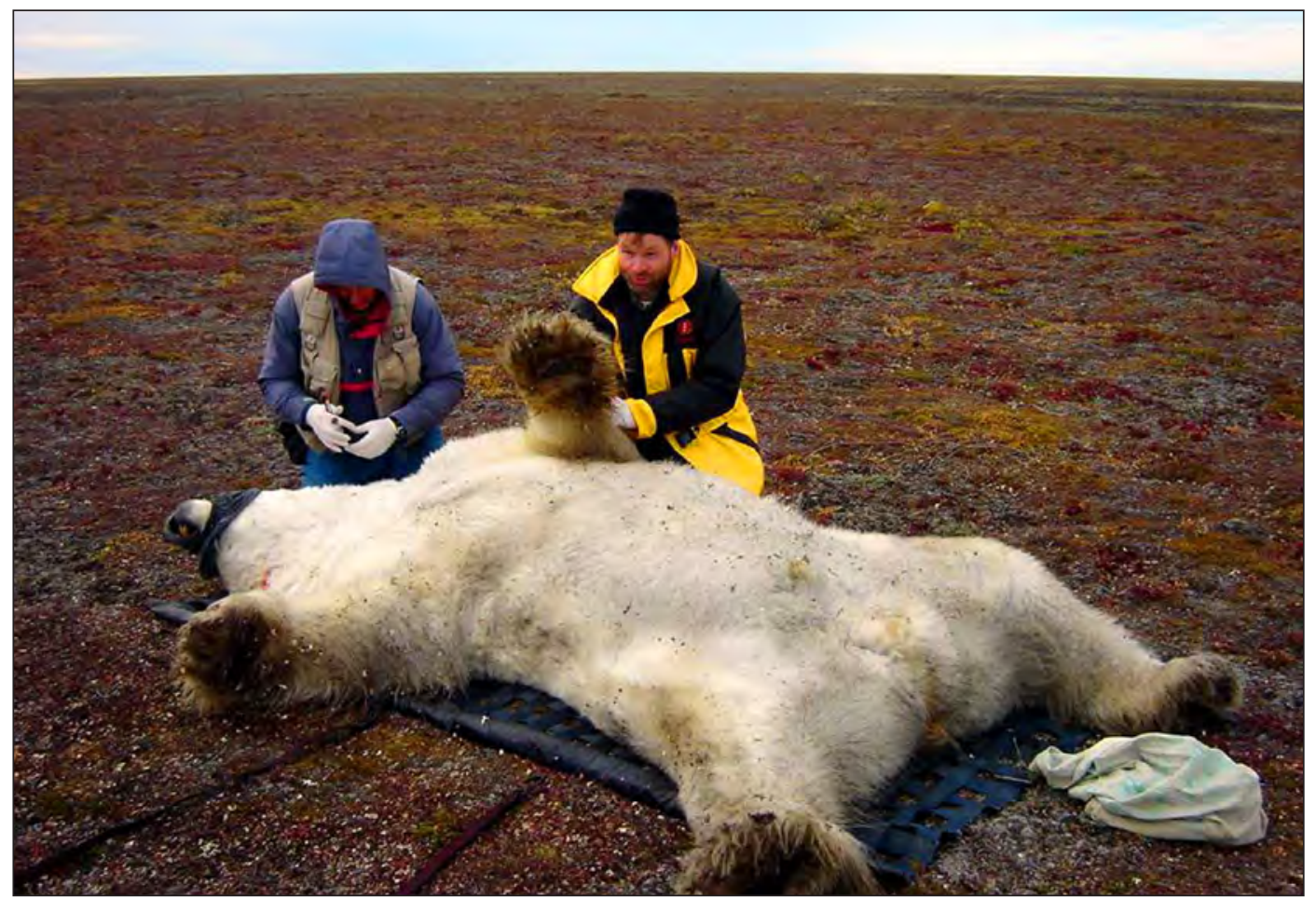

Figure 9. Canadian Wildlife Health Cooperative and Ontario Ministry of Natural Resources and Forestry research personnel prepare to collect a blood sample from an anesthetized adult male polar bear captured along the southern Hudson Bay coastline during the fall season. (Photo courtesy of Ontario Ministry of Natural Resources and Forestry.)

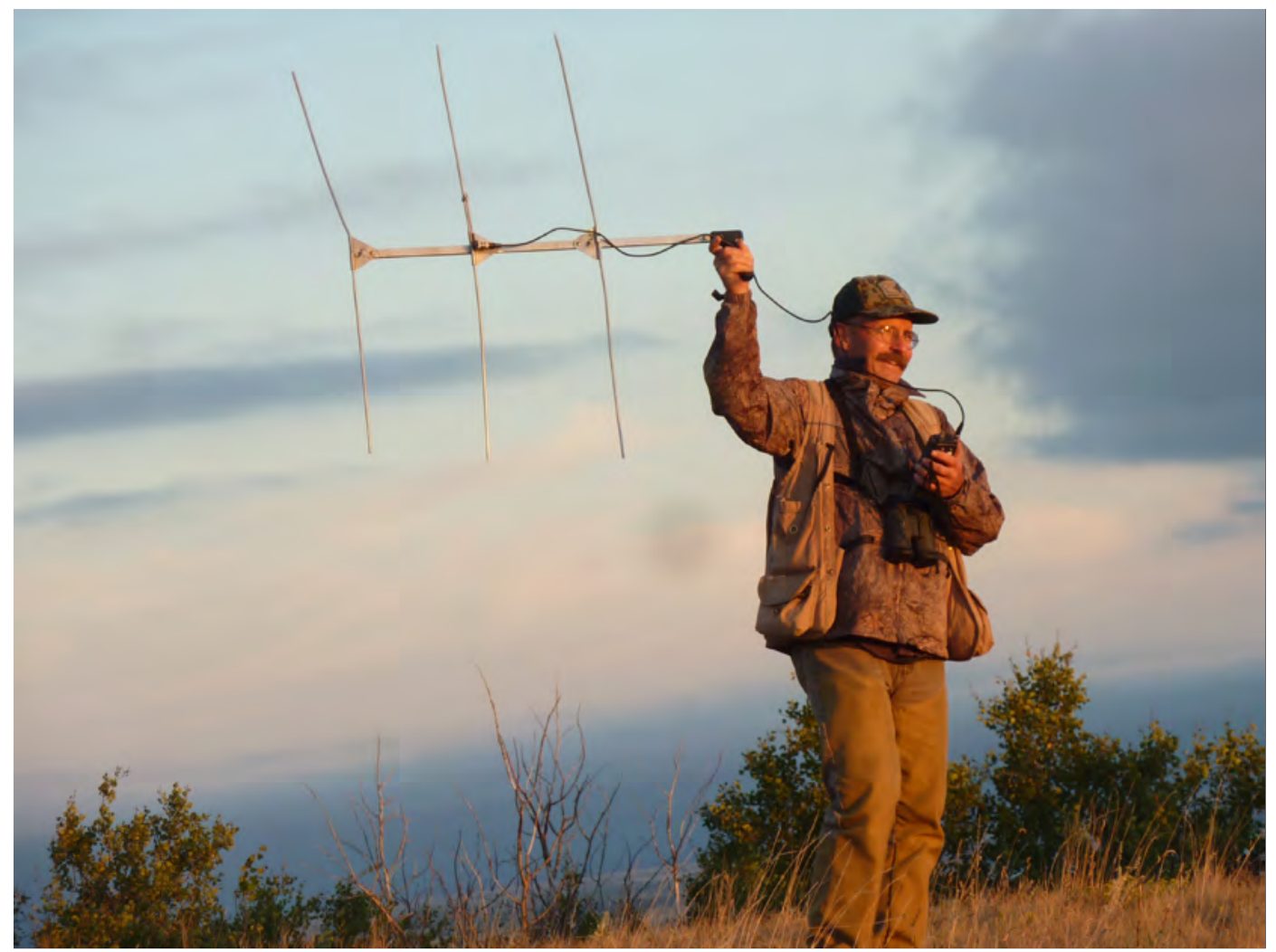

Figure 10. Canadian Wildlife Health Cooperative Western/Northern regional director tracks radiocollared mule deer for a chronic wasting disease research project in southern Saskatchewan, Canada. (Photo courtesy of Canadian Wildlife Health Cooperative.) 
climate change, and other environmental changes. Such associations are "canary in the coal mine" events that can provide early warning of emerging environmental risks to people.

The CWHC provides surge capacity with its cross-Canada infrastructure and accessible network. By maintaining a solid core capacity, the CWHC cannot only detect upcoming risks, but also can more rapidly and efficiently ramp up capacity when emergencies arise than by developing the structures and functions de novo as new emergencies occur. Part of this surge capacity includes providing national and regional coordination for wildlife health management responses across jurisdictions and organizations and integrating information into a single national perspective.

The CWHC members build institutional resilience through capacity development and training, including supporting a wide variety of post-secondary trainees. Academic members of the CWHC are actively engaged in research in a variety of fields, from diagnostics, to pathogenesis, to disease ecology. CWHC members contribute to numerous working groups and committees: representing Canada at international meetings, serving as national sources of expertise, and supporting local management programs. Lastly, the CWHC produces risk assessments, knowledge reviews, policy assessment, and research that inform policy and practice. This includes being a partner institution in an OIE Collaborating Centre that builds international wildlife health capacity.

Other examples of academic institutions increasing their involvement in addressing disease in free-ranging wildlife populations follow.

\section{University of California-Davis-School of Veterinary Medicine}

The School's Karen C. Draper Wildlife Health Center focuses on the health of free-ranging and captive terrestrial and aquatic wildlife.

\section{Colorado State University-College of Veterinary Medicine and Biological Sciences}

The College offers an Infectious Disease Supercluster program that promotes research and practices designed to combat human, animal, and plant infectious diseases worldwide. One unit of the wildlife component specializes in marine mammals on the west coast and Alaska (http://csu-cvmbs. colostate.edu/academics/mip/healthy-oceans-wildlife/Pages/ default.aspx). The college and Colorado Parks and Wildlife have maintained strong collaborative efforts for decades relative to wildlife health issues.

\section{Cornell University-College of Veterinary Medicine}

The College's Wildlife Health Program specializes in diseases among free-ranging and captive wildlife and the impacts of wildlife disease on conservation. Collaboration with the New York State Department of Environmental ConservationWildlife Disease Laboratory and involvement with the Northeast Wildlife Disease Cooperative are other aspects of the college's active involvement in addressing wildlife disease issues of relevance for wildlife conservation agencies.

\section{University of Florida-College of Veterinary Medicine}

The College has an aquatic animal health program, a Marine Animal Disease Laboratory, and an Emerging Pathogens Institute.

\section{University of Georgia-College of Veterinary Medicine}

The College has a clinical wildlife health program and its full service diagnostic and pathology laboratories provide strong support for the wildlife disease investigations at SCWDS. Also, the collaborative relations between SCWDS and the College provide a wealth of training opportunities in wildlife disease for students with career interests in combatting disease in free-ranging wildlife populations.

\section{Michigan State University-College of Veterinary Medicine}

The College's Center for Cooperative Epidemiology studies the epidemiology of diseases in human, domestic animal, and wildlife populations by identifying disease risk factors and prevention methods and comparing various disease processes between animals and humans.

\section{Tufts University Cummings School of Veterinary Medicine}

The School has a specific Wildlife and Conservation Medicine Signature Opportunity for veterinary students concerned with wildlife health and core curriculum courses that assure all of its graduates are exposed to the basics of wildlife health. The School also has a major role within the Northeast Wildlife Disease Cooperative and has maintained an on-campus wildlife health clinic that was established during the early 1980s. 


\section{University of Wisconsin-Madison-School of Veterinary Medicine}

The School offers a general course on diseases of wildlife within the College of Agriculture and Life Science. That open enrollment, jointly sponsored course with the Department of Wildlife Ecology utilizes the School of Veterinary Medicine faculty as well as guest lectures (including adjunct faculty) who are subject-matter experts in the diseases and topics being addressed. Collaborative relations between the School and the NWHC also provide various opportunities for student internships, a wildlife disease seminar series, and collaborative research projects.

The previous are only superficial examples of what is taking place. Virtually all veterinary schools in the continental United States now have some involvement with wildlife disease. Also, major raptor rehabilitation programs exist at the schools of veterinary medicine at the University of Minnesota and the University of California-Davis. Cornell and Tufts are additional veterinary schools having substantial involvement with wildlife rehabilitation.

Veterinary schools are not the only academic institutions providing training and assistance in combatting wildlife disease. Biological science programs within Land Grant and other universities continue to provide much of the training in wildlife disease ecology and the management of such diseases in nature. Fruitful collaborative wildlife projects involving natural resources agencies and the University community have occurred since the earliest wildlife disease investigations were carried out. In addition to research projects, such efforts have included the development of public education materials, special workshops to enhance technical capabilities of agency personnel, and various other types of projects. The point here is that, in general, the University community is an increasing rich source of potential opportunities for collaborative efforts and training that can beneficially assist wildlife conservation agencies in combatting disease in nature. Therefore, it is worthwhile to become familiar with local opportunities and how to call upon them.

\section{Other Programs}

Among the myriad of other programs available for possible assistance are those within the private sector-some of which are for-profit commercial endeavors - and other nonprofit enterprises, professional societies, and general conservation agencies. The collective number of such programs is substantial, and their scope varies from highly focused, limited subject areas such as private sector wildlife immobilization workshops and wildlife rehabilitation clinics to global involvement in wildlife disease research to address wildlife conservation, domestic animal, and public health issues. Many of those programs can provide information about specific disease issues and (or) undertake contract work.

As noted at the start of this Chapter, the programs referred to do not represent a comprehensive listing of the potential sources for assistance available. Furthermore, program citation in this publication is not intended to reflect greater value and (or) competency than programs not listed. Reality is that there is likely to be a continuum of new programs appearing for the foreseeable future and various changes among some of the programs identified in this Chapter.

Assistance being sought should be consistent with the task at hand and deliverable within needed time frames. For example, among the key considerations in seeking assistance relative to the investigation of an active epizootic are the timely processing of specimens and the technical capacity of the sources for assistance to provide multidimensional assessments (for example, necropsy plus specialized diagnostic tests) relative to determining the causative agent involved. Desktop exercises simulating the types of disease issues likely to occur can be highly useful for identifying needs to be addressed and developing expedited pathways for addressing those needs in a timely manner.

\section{Wildlife Disease Information}

"Finding and assessing information about disease and keeping informed about current events and new discoveries is a daunting task because of the diversity of information sources and the great volume of published materials. ... Guidance for effectively traveling the information highway and efficiently negotiating the information maze" (Wesenberg and Friend, 2006) is provided in the publication "Disease Emergence and Resurgence: The Wildlife-Human Connection" (Friend, 2006). In this Chapter, the focus is on North America. Numerous other information sources also are available from programs in other countries.

\section{Field Guides}

Illustrated wildlife disease field guides published by various sources are especially useful to field personnel as rapid basic information sources about individual diseases of wildlife within the geographic area of coverage (table 1). Previous hard copy editions of the current field manual being published electronically by the USGS NWHC were focused on illustrating diseases of free-ranging North American birds (Friend and others, 1987; Friend and Franson, 1999). The current electronic revised edition progressively expands the scope of coverage (as Chapters become available) to illustrate a greater spectrum of the common and emerging diseases of free-ranging North American wildlife. 
Table 1. Examples of illustrated field guides on wildlife disease.

[Modified from Wesenberg and Friend (2006)]

\begin{tabular}{|c|c|}
\hline Title (Author) & Comments \\
\hline $\begin{array}{l}\text { Manual of Common Parasites, } \\
\text { Diseases and Anomalies of } \\
\text { Wildlife in Ontario } \\
\text { (Fyvie, 1969) }\end{array}$ & $\begin{array}{l}\text { First published in 1964, this pocket-size, loose-leaf manual has color photographs of gross lesions } \\
\text { accompanied by brief description of the disease, one to three selected references for more detailed } \\
\text { information, and a form for documenting occurrences of each disease. }\end{array}$ \\
\hline $\begin{array}{l}\text { Handbook of Diseases of } \\
\text { Saskatchewan Wildlife } \\
\text { (Wobeser, 1985) }\end{array}$ & $\begin{array}{l}\text { Addresses causative agent, species affected, occurrence in Saskatchewan, general ecology, clinical } \\
\text { disease, pathology, specimens for diagnosis, and general significance for wildlife. Color photographs } \\
\text { illustrate each disease. }\end{array}$ \\
\hline $\begin{array}{l}\text { Field Guide to } \\
\text { Wildlife Diseases } \\
\text { (Friend and others, 1987) }\end{array}$ & $\begin{array}{l}\text { This original version of the National Wildlife Health Center Field Guide was focused on diseases of } \\
\text { migratory birds and intended to be followed by additional volumes focused on other species groups. } \\
\text { Highly illustrated by large color photographs, the initial section of this field guide focuses on general } \\
\text { field procedures for addressing wildlife disease outbreaks. }\end{array}$ \\
\hline $\begin{array}{l}\text { Wildlife Disease Investigation } \\
\text { Manual (Canadian } \\
\text { Cooperative Wildlife } \\
\text { Health Centre, 1994) }\end{array}$ & $\begin{array}{l}\text { Another of the pocket-size manuals developed to assist field biologsts in the conduct of wildlife disease } \\
\text { investigations. Illustrations are limited to a few black and white drawings. }\end{array}$ \\
\hline $\begin{array}{l}\text { Handbook of Wildlife } \\
\text { Chemical Immobilization- } \\
\text { International edition } \\
\text { (Kreeger and others, 2002) }\end{array}$ & $\begin{array}{l}\text { This handbook is intended to provide wildlife biologists and others with a portable reference for the } \\
\text { chemical capture of wild animals. Contents include drug doses, equipment used for this activity, } \\
\text { regulations, and medical treatment considerations along with other pragmatic information. }\end{array}$ \\
\hline $\begin{array}{l}\text { Restraint and Handling of } \\
\text { Wild and Domestic animals } \\
\text { (Fowler, 1995) }\end{array}$ & $\begin{array}{l}\text { This book presents discussions and illustrations of the principles of animal restraint and describes re- } \\
\text { straint practices for diverse species of vertebrate wild and domestic animals. The techniques discussed } \\
\text { are those used successfully by the author and respected colleagues. Effective drug use and methods } \\
\text { for chemical restraint of animal groups also is addressed. Part } 1 \text { focuses on general concepts, } \\
\text { part } 2 \text { on domestic animals, and part } 3 \text { on wild animals. }\end{array}$ \\
\hline $\begin{array}{l}\text { Field Manual of Wildlife } \\
\text { Diseases in the } \\
\text { Southeastern } \\
\text { United States } \\
\text { (Davidson, 2006) }\end{array}$ & $\begin{array}{l}\text { This highly popular field manual was first published in } 1988 \text { by Davidson and Nettles. An expanded sec- } \\
\text { ond edition was published in } 1997 \text { by the same authors. The current updated version provides } \\
\text { futher expansion of the information provided while maintaining its original format as a "pocket-sized" } \\
\text { reference easily carried into the field. Information is arranged by species and then disease. Color } \\
\text { photographs illustrate the disease condition and (or) parasite. Information is arranged by causative } \\
\text { agent, clinical signs, lesions, hosts, diagnosis, ecology, wildlife management significance, and public } \\
\text { health implications. }\end{array}$ \\
\hline
\end{tabular}




\section{Other Selected Wildlife Disease References}

More detailed information than is provided about specific diseases within field guides is continually being added to the scientific literature and summarized within an expanding array of books and other publications. Some of these publications are focused on specific geographic areas (table 2), some on specific wildlife species or groups of species (table 3 ), and still others on specific types of pathogens (table 4). In addition, there is an increased focus on the ecology of wildlife disease and their management (table 5).

The literature cited in tables $1-5$ provides a basic library of major references for diseases of free-ranging wildlife. Continual advances in knowledge about such diseases indicate that those citations since the mid-1980s are the most useful in addressing current wildlife disease issues. Earlier publications are more useful for evaluations involving changes in the importance of specific diseases and for gaining enhanced understanding relevant to disease ecology and control.

Despite the wealth of information available in the types of publications previously noted, it is important to recognize that the dynamics of wildlife disease emergence and spread surpasses the ability of such literature to stay current for very long. Humanity now lives in an era of unprecedented infectious disease emergence on a global scale (fig. 11). In the time it takes to prepare and publish printed books and other major publications summarizing what is known about wildlife disease, it is likely that several diseases not previously recognized within free-ranging wildlife populations will have appeared. That has certainly been true for my personal attempt to provide a broad overview focused on the wildlife connection as a factor for infectious disease emergence and more recently, for my focus on the questions, "Why Bother About Wildlife Disease?" even though that presentation was published electronically. The challenge involved is readily evident from the major revisions required for publications that were considered comprehensive references at the time of their initial development (for example, tables 3 and 4).

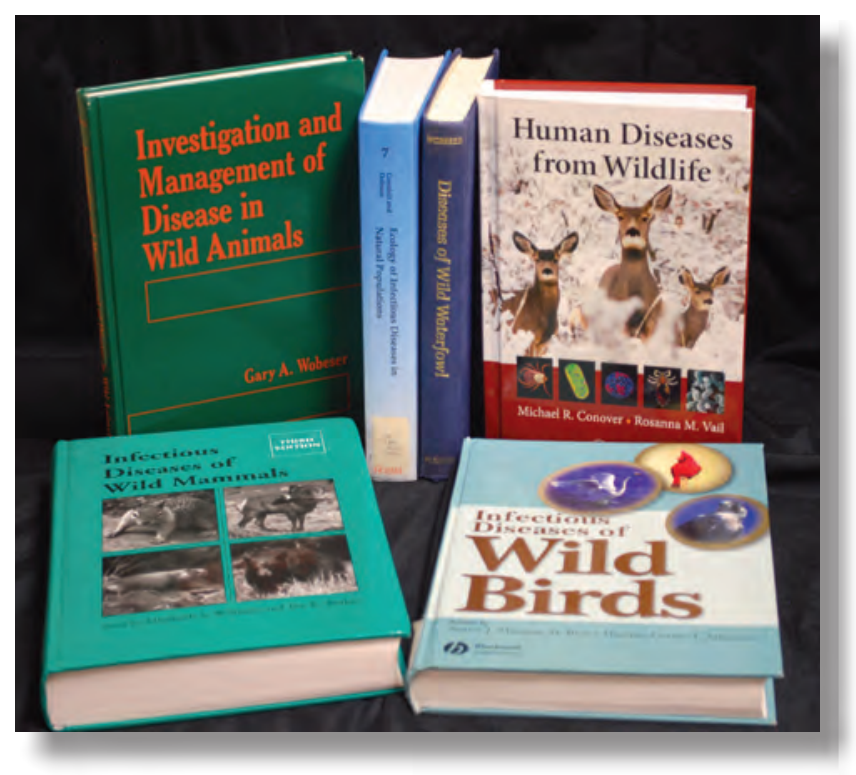

Table 2. Examples of wildlife disease compendiums focused on specific geographic areas.

[Modified from Wesenberg and Friend (2006); see also table 1]

\section{Title (Author)}

Alaskan Wildlife

Diseases

(Dieterich, 1981)

Parasites and Diseases of Wild Mammals in Florida

(Forrester, 1992)

Parasites and Diseases of Wild Birds in Florida (Forrester and Spalding, 2003)

Wildlife Pathogens in Canada (Leighton, 2011)

\section{Comments}

This publication condenses published information of that time on diseases of wildlife in Alaska for the purpose of providing basic information about those diseases. Symptoms and lesions are highlighted and disease is considered broadly to include starvation, stress, trauma and other debilitating conditions. Part I focuses on mammals, part II on birds, part III on fish, and part IV on invertebrates.

As stated by the author, this publication is not a diagnostic manual but the illustrations and information provided can assist in that task. This book is intended to be a reference providing data on the distribution, prevalence, and significance of the parasites and diseases included. The chapters are organized by species of mammal rather than by disease.

This companion publication to the above wild mammal book follows a similar format. The emphasis is on the distribution and prevalence of the causes of morbidity and mortality in Florida's wild birds. Information provided covers all species. These two books on Florida wildlife provide a rare, in-depth assemblage of information about the disease of wildlife within a single State and serve as an important baseline for disease investigations involving Florida wildlife.

This technical report reviews the status of a selection of diseases in Canadian wildlife. An accounting of the ecozones within the range of each pathogen is included (Leighton, 2011). 
Table 3. Examples of wildlife disease compendiums focused on specific wildlife species.

[Modified from Wesenberg and Friend (2006)]

Title (Author)

Comments

\begin{abstract}
Infectious Diseases of Wild This benchmark Iowa State Univeristy Press publication prepared by wildlife disease specialists of that time Mammals (Davis and others, 1970) was the first in a series of books summarizing information about disease in free-ranging wild mammals. An expanded and updated second edition by the same editors was published in 1981.

Parasitic Diseases of Wild Mammals (Davis and Anderson, 1971)

Infectious and Parasitic Diseases of Wild Birds (Davis and others, 1971)

Diseases of the Reptilla (Cooper and Jackson, 1981)

This second in the benchmark series of Iowa State University Press reference books on wildlife disease is focused on the common and important parasites of wild mammals and the diseases that ensue from that parasitism.

This is the third book in the Iowa State University Press series of benchmark reference books on wildlife disease. It is noteworthy that later additions resulted in separate books for infectious diseases and parasites because of the increased significance of disease caused by both types of pathogens.

Volume 1 covers infectious diseases, and volume 2 covers noninfectious diseases. This was the first book on this subject written by specialists in diseases of reptiles, and it provides a good baseline for comparative evaluations.

Diseases and Parasites of White-tailed Deer (Davidson and others, 1981)

This baseline publication involving 41 authors focuses on the health and diseases of a single species-the white-tailed deer. Current information of that time for all salient noninfectious and infectious disease conditions were addressed. Notably, chronic wasting disease (CWD) had not yet become an issue in North America. Nevertheless, this book remains an important source for information involving disease in this species.

Diseases of Amphibians and Reptiles (Hoff and others, 1984)

This book on diseases of free-ranging and captive "herptiles" was an attempt to bring together what was known at that time about the diseases of those species long before chytrid fungus became a global headline. Primarily organized by disease, noninfectious as well as infectious diseases are addressed.

Diseases of Wild Waterfowl (Wobeser, 1997)

CRC Handbook of Marine Mammal Medicine (Dierauf and Gulland, 2001)

First published in 1981, this book remains an important reference for diseases of free-ranging waterfowl.

This is the only handbook specifically devoted to marine mammal medicine and health. This expanded second edition addresses marine mammals as sentinels for ocean health and highlights emerging and resurging diseases. Cetaceans, pinnipeds, manatees, sea otters, and polar bears are the focus for the disease chapter. In addition, Section III provides an overview of infectious diseases of marine mammals with chapters on viral diseases, bacterial diseases of cetaceans and pinnipeds, mycotic diseases, parasitic diseases, toxicology, and noninfectious diseases. Additional information about disease is provided in Section IV chapters on various types of species such as seals and sea lions, walruses, manatees, sea otters, and polar bears.
\end{abstract}

Infectious Diseases of Wild This updated component of the wild mammal segment of the original Iowa State University Press series of Mammals (3d ed.) (Williams and Barker, 2001)

Parasitic Diseases of Wild Mammals (Samuel and others, 2001) books on wildlife disease currently serves as an important reference on its subject area.

This extensively revised edition of the earlier 1971 publication contains original, previously unpublished information. Parasitic groups covered are ectoparasites, helminths or endoparasites, and protozoans. Key discussion points include disease emergence, factors involved in the development of some parasites into pathogenic agents, and parasite groups of public health concern.

Infectious Diseases of Wild This updated and expanded wild bird edition of the original Iowa State University Press series does not Birds (Thomas and others, 2007) include parasitic diseases. Section 1 of the book addresses viral diseases; Section 2 addresses bacterial and fungal diseases; and despite the title of the book, Section 3 focuses on biotoxins (avian botulism, mycotoxins, and algal biotoxins), none of which are infectious but all of which have living agents as their pathogens

Parasitic Diseases of Wild This stand-alone publication of the earlier Iowa State University Press publication of "Infectious and Parasitic Birds (Atkinson and others, 2008)

Diseases of Wild Birds" is another benchmark reference book on wildlife disease. Section I examines the costs and effects of parasitism and is followed by sections addressing protozoa, helminths, leeches, and ectoparasitic arthropods. 
Table 4. Examples of wildlife disease compendiums focused on specific types of pathogens.

Title (Author)

The Natural History $\begin{aligned} & \text { The } 1975 \text { two-volume original edition was a seminal publication. Since then, much has changed in the ecol- } \\ & \text { ogy of wildlife rabies and the options available to combat this dreaded disease of human antiquity. This } \\ & \text { of Rabies } \\ & \text { second edition established a new baseline of knowledge and perspectives for combatting rabies. Seven of } \\ & \text { the nine chapters in the section on epidemiology address wildlife, specifically the disease in Arctic foxes, } \\ & \text { skunks, raccoons, nonhematophagus bats, vampire bats, and rodents. Oral immunization of wildlife is } \\ & \text { highlighted by a chapter within the section on rabies control. }\end{aligned}$

Handbook of Zoonoses Section B: Viral Zoonoses (Beran, 1994)

This series of books continues to be a preferred reference work despite having been published prior to the more recent occurrences for some important zoonotic diseases. Content identifies animal diseases that are host specific and reviews the effects of various human diseases on animals. The emphasis for each zoonosis is on the epidemiology of the disease, the clinical syndrome and carrier states in infected animals and humans, and current methods for diagnosis and approaches to control.

This final book in the original four-book Iowa State University Press series on diseases of wildlife has its greatest focus on environmental contaminants. This expanded second edition also addresses dental anomalies, amyloidosis, capture myopathy, shock, physical injury, mycotoxins, and geophagy in individual chapters. There also is a chapter devoted to forensic investigational techniques.

Chemical Risk Assessment: Health Hazards to Humans, Plants, and Animals (Eisler, 2000)

This handbook provides a compilation of the appropriate amount of information needed to support adequate chemical risk assessments for humans, plants, and animals. Each entry is listed alphabetically and includes information relative to its sources and use; physical, chemical, and metabolic properties; concentrations in field collections of abiotic materials and living organisms; deficiency effects; lethal and sublethal effects; and proposed regulatory critera to protect human health and that of sensitive natural resources. Volume 1 focuses on metals, volume 2 on organics, and volume 3 on metalloids and radiation as well as providing a cumulative index to chemicals and species.

Zoonoses and Communicable Diseases Common to Man and Animals (Acha and Szyfres, 1987)

This publication has been a personally useful desktop reference frequently turned to during my career. In 2000 , volume 1 of what was to be a four-volume updated and expanded version of this classic book was published and addressed bacterioses and mycoses. Volume 2 (chlamydiosis and rickettsiosis) followed and in 2003 volume 3 (parasitosis) followed. Volume 4 was expected to address viroses but has not appeared.

Handbook of Ecotoxicology (Hoffman and others, 2003)

Bat Rabies and Other Lyssavirus Infections (Constantine, 2009)

Ingestion of Lead From Spent Ammunition: Implications for Wildlife and Humans (Watson and others, 2009)

Environmental
Contaminants in Biota:
Interpreting Tissue
Concentrations
(Beyer and Meador, 2011)

This completely revised and updated second edition represents the most comprehensive and authoritative work of its kind. Additions include a new section, "Special Issues in Exotoxicology" that focuses on exposure and sensitivity of amphibians to environmental contaminants, endocrine disrupters, genetic effects of environmental contaminants, the indirect effects of agricultural pesticides on wildlife, trace element and nutrition interactions, and the role of ecotoxicology in industrial ecology and in natural capitalism. The above and much more of the content results in this book being a definitive reference for a broad audience within the scientific, industrial, and general public arenas.

This downloadable publication focuses on the global occurrence of rabies in bats, its origins, how it spreads, and the degree of threat it poses to people, pets, farm animals, and wildlife.

The collective presentations published in this conference proceedings begin with a focus on providing a contemporary review of lead uptake and toxicosis in humans and wildlife and then moves to lead exposure, sources, and toxicosis in wildlife. The concluding presentations address remediation of lead exposure from spent ammunition. This symposium was the first to focus attention on human health implications of lead from the consumption of hunter bagged wild game.

This updated edition incorporates current data and advances in data analysis as well as including contaminants not previously considered. Reviews that address dichlorodiphenyltrichloroethan (DDT), mercury, and dioxins, polybrominated diphenyl ethers (PBDEs) in aquatic organisms, birds, and mammals; selenium in birds and fish, trace metals in aquatic invertebrates and marine mammals; pharmaceuticals and pesticides in marine species; organic contaminants in marine mammals; and cyclodiene and other organochlorine pesticides in birds and mammals are all considered in this important publication. 
Table 5. Examples of wildlife disease-oriented books focused on disease ecology and management.

Title (Author)

\begin{tabular}{|c|c|}
\hline $\begin{array}{l}\text { Investigation and } \\
\text { Management of } \\
\text { Disease in Wild Animals } \\
\text { (Wobeser, 1994) }\end{array}$ & $\begin{array}{l}\text { The Introduction of this book provides perspectives relative to basic principles and unique problems in } \\
\text { working with free-living wildlife. The author then focuses on disease investigation principles } \\
\text { and concludes his presentation by focusing on disease management. }\end{array}$ \\
\hline $\begin{array}{l}\text { Diseases in Wild Animals: } \\
\text { Investigation and Management } \\
\text { (2d ed.) (Wobeser, 2007) }\end{array}$ & $\begin{array}{l}\text { This outstanding publication by one of North America's leading wildlife disease investigators provides } \\
\text { the most comprehensive and cohesive presentation available on the management of disease in } \\
\text { free-ranging populations. }\end{array}$ \\
\hline $\begin{array}{l}\text { The Ecology of Wildlife } \\
\text { Diseases } \\
\text { (Hudson and others, 2009) }\end{array}$ & $\begin{array}{l}\text { This book is a synthesis of ideas for focusing the wildlife disease ecology research agenda, primarily } \\
\text { from a modeling perspective. The focus is to apply an ecological approach to an understanding of epi- } \\
\text { demiology in wild animal populations. Spatial aspects of disease dynamics, the ecology of tick-borne } \\
\text { infections in wildlife reservoirs, microparasite transmission and persistence, and the role of pathogens } \\
\text { in biological conservation are some of the subject areas addressed. }\end{array}$ \\
\hline
\end{tabular}




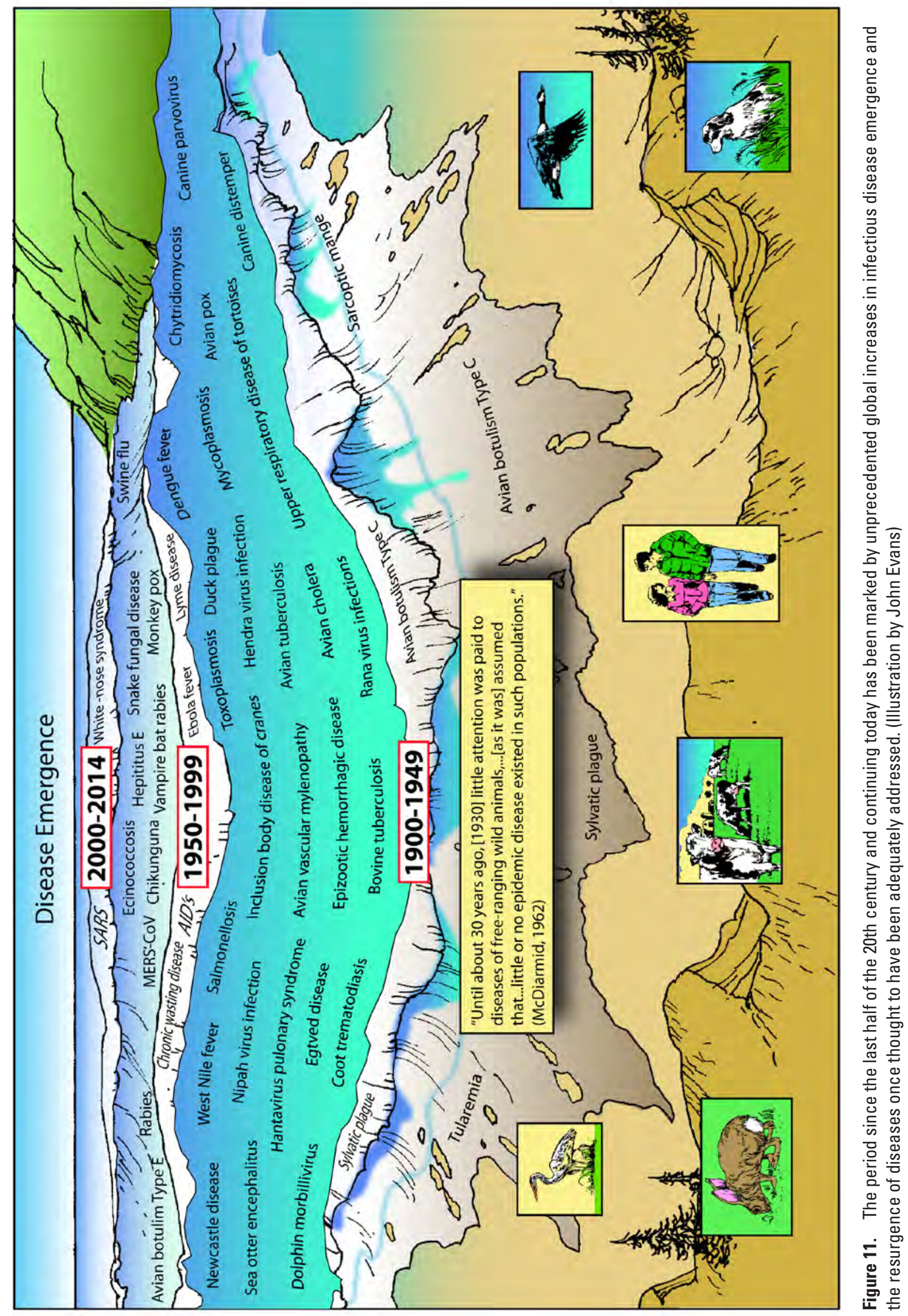




\section{Online Publications}

Online information transfer has become the primary medium for obtaining much of the information we seek, including that about wildlife disease. Online publishing of scientific journals has been embraced, and real-time reporting of information about disease events by various sources has become mainstream. It is important to know if postings are supported by adequate subject-specific peer-review evaluations and (or) other quality-control processes because virtually anyone can post statements and information online. It is prudent to restrict the use of the multitude of online sources that are available to those whose credibility is above reproach.

The following examples highlight some online sources commonly used by those contributing to and (or) seeking information involving wildlife diseases. No inferences should be drawn about sources not included among the examples given as none are intended. Instead, the personal use or rejection of individual sources should be made by the user.

In today's world, it has become common for State wildlife conservation agencies to post bulletins, news releases, and other items about wildlife health issues and zoonoses on their respective agency Web site. Such postings tend to be of local interest and at a general information level, even when focused on technical matters. Information relative to a broader audience tends to be primarily posted on the Web sites of the larger wildlife disease programs and those of some professional societies. For example, the CWHC provides a wealth of information that can be downloaded. Their Web site also provides a list of the CWHC recent publications. SCWDS publishes its long-standing (began year 30 in 2015) "SCWDS Briefs Newsletter" on a quarterly basis. In addition to interesting information about the Center's activities, informative briefs about current mortality events and new information about specific diseases of interest are provided. The full text of previously published issues of that Newsletter (beginning with the year 1999) can be searched on the University of Nebraska Digital site.

At the Federal level, the USGS NWHC Web site provides postings of Wildlife Health Bulletins issued by the NWHC to highlight important faunal morbidity and mortality events. The NWHC also issues fact sheets about high interest emerging wildlife disease issues such as "White-Nose Syndrome in Bats;" those updating persistent high profile diseases of concern such as CWD in deer and "Lead Poisoning in Wild Birds;" and those focused on disease management such as "Sylvatic Plague Vaccine and Management of Prairie Dogs." Consult the NWHC Web site for other publications that can be downloaded and (or) are available on CDs.

Considerable current information about emerging infectious diseases can be found within publications of the U.S. Public Health Service Centers for Disease Control (CDC) because the majority of such diseases have wildlife origins. The CDC publishes "Emerging Infectious Diseases," a monthly peer reviewed, open access scientific journal, ranked number 3 of 70 infectious disease journals. Now in its 21 st year of publication (2015), a print version and full text downloads of each article are both available. The CDC also publishes "Morbidity and Mortality Weekly Report" (MMWR), a long-standing public health publication-now at Volume 64 (2015) — that provides notices, short articles about current disease issues, and other information such as "MMWR Surveillance Summaries" that often contain information about wildlife. A current example involves human trichinosis cases linked with the consumption of bear and deer meat.

There are an increasing number of Internet-based reporting systems dedicated to rapid dissemination of information on disease events. ProMED-mail is a well-established program of that type. Its acronym states its purpose as the "Program for Monitoring Emerging Diseases." Sources of information include media reports, online summaries, local observers, and others. Information is screened by subject-matter experts who evaluate the reports, posting only those that are determined to be accurate and credible. Postings are immediately distributed by email to direct subscribers and also placed on the ProMED Web site. Postings occur 7 days a week and cover a broad range of situations involving outbreaks of infectious diseases and acute exposures to toxins that effect human health, including those in animals and in plants grown for food or animal feed. Despite the program being focused on human health, a wealth of information about wildlife involvement in disease events appears in these postings.

Whitenosesyndrome.org is an example of an online information exchange program focused on a single disease-whitenose syndrome in bats. This Web site contains information about the disease including publications, maps, video, audio, photographs, media news items, and access to a blog focused on this subject.

The USGS NWHC also has developed a Wildlife Health Information Partnerships event reporting system (WHISPers). This system upgrades the nearly 40 -year effort by the NWHC to collect and distribute information on wildlife mortality and morbidity events. Quarterly summaries of these data have been published in the Supplement to the "Journal of Wildlife Diseases" since 1987. These reports (dating to 1981) can now be viewed online. The concept for WHISPers was developed by the NWHC in partnerships with Federal, State, Tribal, nongovernmental, and academic partners. This system is designed to track laboratory-confirmed wildlife mortality events. These events can be entered with an "unknown" cause and records updated if and (or) when laboratory confirmation is received. The primary intended audience is natural resource managers who need timely situational awareness of such events. For additional information about WHISPers and to request a user login, contact the USGS NWHC.

Another developing wildlife mortality reporting program is the Wildlife Data Integration Network (WDIN). This collaborative project is pursuing the development of a Webbased monitoring and reporting system for providing natural resources managers and others (including the general public) 
with access to data on wildlife diseases, mortality events, and associated related information. Data are contributed voluntarily, with partners deciding which data they chose to share. WDIN Highlights is a monthly publication of WDIN that promotes the Network's products, functions, and resources. Although written for wildlife health specialists, wildlife managers and the general public also will find much of the information provided to be of interest and value.

The Seabird Ecological Assessment Network (SEANET) is an example of a citizen science wildlife mortality event notification system. This program brings together interdisciplinary researchers and members of the public in a persistent effort to identify and mitigate threats to marine birds. Since the programs origin (2002) in Massachusetts, it has extended throughout New England, New York, and New Jersey to South Carolina, Georgia, and Florida. Program volunteers in each State conduct year-round beached bird surveys for the purpose of identifying and recording information about bird mortality. Those data are used to examine the spatial pattern of bird carcass deposition and how it varies across time. These surveys provide baseline information about bird mortality and can help to detect mass mortality events. Information transfer for this program is largely via SEANET blog. The Coastal Observation and Seabird Survey Team (COASST) (https://depts. washington.edu/coasst/what/vision.html) and Coastal Ocean Mammal and Bird Education and Research Surveys (Beach COMBERS) (http://www.sanctuarysimon.org/monterey/sections/beachCombers/index.php?l=n) are two additional citizen science event notification systems that gather information on areas along the western U.S. coasts.

Professional societies concerned with the well-being of natural resources also are utilizing online media to highlight wildlife disease issues and concerns. This can be seen in part by the frequent postings of short articles and videos on The Wildlife Society (TWS) Web page, "Science and Management News." As would be expected, the Wildlife Disease Associations (WDA) has become heavily invested in online information transfer, including linkage to "Wildlife News" and
"Wildlife Disease News Digest." The latter provides access to the WDIN blog. The WDA also has a Twitter page where dialogue takes place on various issues.

The previous examples are just that, examples of the types of online programs for wildlife disease reporting and information exchange that exist and (or) are being developed. Some of these programs will flourish over time, and others be abandoned for various reasons. All have merit and all face substantial hurdles to overcome before achieving institutional status enjoyed by major public health and domestic animal disease reporting systems. Clearly, continued advances in electronic data and reporting systems are a major asset for advancing wildlife disease information exchange and need to be fully embraced both at the input and sharing stages. It is hoped that readers of this Chapter will be stimulated to do both.

Multidisciplinary partnerships involving wildlife and land management professionals, and wildlife research and wildlife health professionals is essential in order to understand the interactions between wildlife disease agents, their hosts, and the environment across the landscape and to be prepared to respond to disease emergence and resurgence. With a multidisciplinary approach, the study of individual diseases can provide critical information on characteristics of susceptible populations, etiological agents, and environmental conditions on different landscape scales that contribute to epizootics and disease emergence. Epidemiologic studies that result in predictive inference can be used to develop ecological, epidemiological, and population models. Predictive modeling of disease processes such as transmission rates, change in spatial distributions through time, sensitivity to environmental conditions, and ability to cross species boundaries can be used to help predict the risk posed by an emerging disease and prioritize diseases that represent significant threats to wildlife, humans, and (or) livestock. Through this understanding of diseases and disease processes, management strategies to prevent, control, or minimize impacts can be developed to protect the Nation's wildlife, agricultural, and human resources. 


\section{References Cited}

Acha, P.N., and Szyfres, B., 1987, Zoonoses and communicable diseases common to man and animals ( $2 \mathrm{~d}$ ed.): Washington, D.C., Pan American Health Organization, Scientific Publication no. 503, 963 p.

Adrian, W.J., ed., 1981, Manual of common wildlife diseases in Colorado: Denver, Colo., Colorado Division of Wildlife, $139 \mathrm{p}$.

Atkinson, C.T., Thomas, N.J., and Hunter, D.B., eds., 2008, Parasitic diseases of wild birds: Ames, Iowa, Wiley-Blackwell, 595 p.

Baer, G.M., ed., 1991, The natural history of rabies (2d ed.): Boca Raton, Fla., CRC Press, 620 p.

Beran, G.W., ed., 1994, Handbook of zoonoses, Section B-Viral zoonoses (2d ed.): Boca Raton, Fla., CRC Press, 608 p.

Beyer, W. N., and Meador, J.P., eds., 2011, Environmental contaminants in biota-Interpreting tissue concentrations (2d ed.): Boca Raton, Fla., CRC Press, 751 p.

Canadian Cooperative Wildlife Health Centre, 1994, Wildlife disease investigation manual: Saskatoon, Canadian Cooperative Wildlife Health Centre, 96 p.

Collinge, S.K., and Ray, C., eds., 2006, Disease ecologyCommunity structure and pathogen dynamics: New York, Oxford University Press, 227 p.

Constantine, D.G., 2009, Bat rabies and other Lyssavirus infections: U.S. Geological Survey Circular 1329, 68 p.

Cooper, J.E., and Jackson, O.F., 1981, Diseases of the Reptilia: London, Academic Press, 2 vols.

Davidson, W.R., ed., 2006, Field manual of wildlife diseases in the Southeastern United States (3d ed.): Athens, Ga., Southeastern Cooperative Wildlife Disease Study, 448 p.

Davidson, W.R., Hayes, F.A., Nettles, V.F, and Kellogg, F.E., eds., 1981, Diseases and parasites of white-tailed deer: Tallahassee, Fla., Southeastern Cooperative Wildlife Disease Study, 458 p.

Davis, J.W., and Anderson, R.C., eds., 1971, Parasitic diseases of wild mammals: Ames, Iowa State University Press, $364 \mathrm{p}$.

Davis, J.W., Anderson, R.C., Karstad L., and Trainer, D.O., eds., 1971, Infectious and parasitic diseases of wild birds: Ames, Iowa State University Press, 344 p.

Davis, J.W., Karstad, L.H., and Trainer, D.O., eds., 1970, Infectious diseases of wild mammals: Ames, Iowa State University Press, $421 \mathrm{p}$.
Dierauf, L.A., and Gulland, F.M.D., eds., 2001, CRC handbook of marine mammal medicine ( $2 \mathrm{~d}$ ed.): Boca Raton, Fla., CRC Press, 1,063 p.

Dieterich, R.A., ed., 1981, Alaskan wildlife diseases: Fairbanks, University of Alaska, 524 p.

Eisler, R., 2000, Handbook of chemical risk assessmentHealth hazards to humans, plants, and animals: Boca Raton, Fla., CRC Press, 3 vols.

Fairbrother, A., Locke, L.N., and Hoff, G.L., eds., 1996, Noninfectious diseases of wildlife ( $2 \mathrm{~d}$ ed.): Ames, Iowa State University Press, 219 p.

Forrester, D.J., 1992, Parasites and diseases of wild mammals in Florida: Gainesville, University Press of Florida, 459 p.

Forrester, D.J., and Spalding, M., 2003, Parasites and diseases of wild birds in Florida: Gainesville, University Press of Florida, 1,132 p.

Fowler, M.E., 1995, Restraint and handling of wild and domestic animals (2d ed.): Ames, Iowa State University Press, 383 p.

Friend, M., 1995, Conservation landmarks-Bureau of Biological Survey and National Biological Service, in LaRoe, E.T., Farris, G.S., Puckett, C.E., Doran, P.D., and Mac, M.J., eds., Our living resources-A report to the nation on the distribution, abundance, and health of U.S. plants, animals, and ecosystems: Washington, D.C., U.S. Department of the Interior, National Biological Service, p. 7-9.

Friend, M., 2006, Disease emergence and resurgence-The wildlife-human connection: U.S. Geological Survey Circular 1285, 388 p., available online at http://www.nwhc. usgs.gov/publications/disease_emergence/index.jsp.

Friend, M., and Franson, J.C., eds., 1999, Field manual of wildlife diseases - General field procedures and diseases of birds: U.S. Geological Survey, Biological Resources Division, Information and Technology Report 1999-001, 367 p., 8 app., available online at http://www.nwhc.usgs. gov/publications/field_manual/index.jsp.

Friend, M., Laitman, C.J., and Kampen, R.S., eds., 1987, Field guide to wildlife diseases-Volume 1. General field procedures and diseases of migratory birds: U.S. Fish and Wildlife Service Resource Publication 167, 225 p., 5 app., 2 glossaries.

Friend, M., and Pearson, G.L., 1973, Duck plague-The present situation, in Proceedings of the Annual Conference of Western Association of State Game and Fish Commissioners: p. 315-325.

Fyvie, A., 1969, Manual of common parasites, diseases, and anomalies of wildlife in Ontario: Toronto, Ontario Department of Lands and Forests, 84 p. 
Hoff, G.L., Frye, F.L., and Jacobson, E.R., eds., 1984, Diseases of amphibians and reptiles: New York, Plenum Press, 784 p.

Hoffman, D.J., Rattner, B.A., Burton, G.A., Jr., and Cairns, J., Jr., eds., 2003, Handbook of ecotoxicology (2d ed.): Boca Raton, Fla., CRC Press, 1,290 p.

Honess, R.F., and Winter, K.B., 1956, Diseases of wildlife in Wyoming: Cheyenne, Wyoming Game and Fish Commission, 279 p.

Hudson, P.J., Rizzoli, A., Grenfell, B.T., Heesterbeck, H., and Dobson, A.P., eds., 2009, The ecology of wildlife diseases: New York, Oxford University Press, 197 p.

Kayunze, K.A.; Kiwara, Angwara; Lyamuya, Eligius; Kambarage, D.M.; Rushton, Jonathan; Coker, Richard; and Kock, Richard, 2014, Practice of One Health approachesBridges and barriers in Tanzania: Journal of Veterinary Research, v. 81, no. 2, 8 p., accessed Sept. 8, 2015, at http:// www.ojvr.org/index.php/ojvr/article/view/733.

Kreeger, T.J., Arnemo, J.M., and Raath, J.P., 2002, Handbook of wildlife chemical immobilization, International Edition ( $2 \mathrm{~d}$ ed.): Fort Collins, Colo., Wildlife Pharmaceuticals, 412 p.

Leighton, F.A., 2011, Wildlife pathogens and diseases in Canada-Canadian biodiversity-Ecosystem status and trends 2010: Ottawa, Ontario, Canadian Councils of Resource Ministers, Technical Thematic Report no. 7, 53 p.

Mahy, B.W.J., and Brown, C.C., 2000, Emerging zoonoses: Crossing the species barrier: Revue Scientifique et Technique, Office International des Epizooties, v. 19, p. 33-40.

Meteyer, C.U., 2000, Field guide to malformations of frogs and toads - With radiographic interpretations: U.S. Geological Survey Biological Science Report 2000-0005, 20 p.

Ostfeld, R.S., Keesing, F., and Eviner, V.T., eds., 2008, Infectious disease ecology-Effects of ecosystems on disease and of disease on ecosystems: Princeton, N.J., Princeton University Press, 506 p.
Samuel, W.H., Rybus, M.J., and Kocan, A.A., eds., 2001, Parasitic diseases of wild mammals ( $2 \mathrm{~d}$ ed.): Ames, Iowa State University Press, 559 p.

The World Bank, 2010, People, pathogens and our planetVolume 1-Towards a One Health approach for controlling zoonotic diseases: Washington, D.C., Agriculture \& Rural Development Department, Report no. 50833-GLB, 56 p.

Thomas, N.J., Hunter, D.B., and Atkinson, C.T., eds., 2007, Infectious diseases of wild birds: Ames, Iowa, Blackwell Publishing Professional, 484 p.

Thorne, E.T., Kingston, N., Jolley, W.R., and Bergstrom, R.C., eds., 1982, Diseases of wildlife in Wyoming (2d ed.): Cheyenne, Wyoming Game and Fish Department, 353 p.

Watson, R.T.; Fuller, Mark; Pokras, Mark; and Hunt, Grainger, eds., 2009, Ingestion of lead from spent ammunitionImplications for wildlife and humans: Boise, Idaho, The Peregrine Fund, 383 p.

Wesenberg, K., and Friend, M., 2006, How to find and access published information on emerging infectious diseases, in Friend, M., Disease emergence and resurgence-The wildlife-human connection: U.S. Geological Survey Circular 1285, p. 275-299.

Williams, E.S., and Barker, J.N., eds., 2001, Infectious diseases of wild mammals ( $3 \mathrm{~d}$ ed.): Ames, Iowa State Press, $558 \mathrm{p}$.

Wobeser, G.A., 1985, Handbook of diseases of Saskatchewan wildlife: Saskatoon, Canada, Saskatchewan Parks and Renewable Resources, 65 p.

Wobeser, G.A., 1994, Investigation and management of disease in wild animals: New York, Plenum Press, 265 p.

Wobeser, G.A., 1997, Diseases of wild waterfowl (2d ed.): New York, Plenum Press, 324 p.

Wobeser, G.A., 2006, Essentials of disease in wild animals: Ames, Iowa, Blackwell Publications, 243 p.

Wobeser, G.A., 2007, Diseases in wild animals - Investigation and management (2d ed.): New York, Springer, 393 p. 




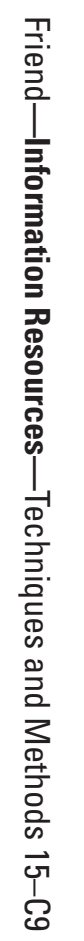

